\title{
VÝSLEDKY ARCHEOLOGICKÉHO VÝZKUMU PALACKÉHO NÁMĚSTÍ V POČÁTKÁCH (OKRES PELHŘIMOV)
}

\author{
JAKUB TĚSNOHLÍDEK - PETR DUFFEK - KATEŘINA TĚSNOHLÍDKOVÁ - MA- \\ RIE PRACHAŘOVÁ - MARKÉTA SKOŘEPOVÁ - TOMÁŠ JANOUŠEK - MICHAELA \\ STANČÍKOVÁ
}

\begin{abstract}
Abstrakt: Hlavním předmètem článku je vyhodnoceni záchranného výzkumu na Palackého námèstí v Počátkách provedeného jihlavským pracovištém Archaia Brno, o. p. s. Počátecko patř́ k málo poznaným regionům, proto bylo souběžněs archeologickým výzkumem přikročeno k revizi historických pramenů. Nejstarši prozkoumané situace souvisely se vznikem města ve 13. století. Zkoumány byly situace spojené s několika velkými požáry v letech 1653-1821. Nejmladši zkoumané situace pocházely z počátku 19. století, kdy došlo k uzavřeni staršich situaci na náměsti kamennou zádlažbou. Těžištěm výzkumu bylo odkrytí bývalého městského hřbitova u kostela sv. Jana Křtitele zrušeného na počátku 19. století. Vyzvednuty byly kostry 228 jedinců, které byly podrobeny antropologické analýze. Výzkum v těsné blizkosti kostela se zaměril na odhalení staršich stavebnich fází. Výsledky výzkumu pomohly výrazně doplnit dějiny města.
\end{abstract}

Klíčová slova: středověk - novověk - hřbitov-keramika - antropologie.

\section{Results of Archaeological Research into Palackého náměstí Square in Počátky (Pelhřimov District)}

Abstract: This article seeks to assess rescue research in Palackého náměsti Square in Počatky conducted by the Jihlava branch of the Archaia Brno company. The Počatky region is among those that have yet to be studied in depth, which is why a revision of historical sources was carried out in parallel with archaeological research. The earliest investigated contexts were related to the establishment of the town in the 13th century, while further contexts were associated with several devastating fires in the years 1653-1821. The most recent contexts dated from the beginning of the 19th century when the earlier ones in the town square were closed by stone paving. The research focused on the unearthing of a former cemetery by the Church of St. John the Baptist that ceased to exist in the early 19th century. The excavations yielded skeletons of 228 individuals some of which were subjected to anthropological analysis. Research in close proximity of the church centred on its earliest building phases. The results of the research significantly contributed to the overall picture of the town's history.

Key words: Middle Ages - modern age - cemetery - pottery - anthropology.

\section{1 Úvod}

V roce 2015 provedlo jihlavské pracoviště společnosti Archaia Brno, o.p. s., plošný záchranný výzkum při rekonstrukci Palackého náměstí v Počátkách. Akce volně navazovala na předešlý výzkum, uskutečněný při stavbě odpadních a vodovodních sítí na počáteckém náměstí (Černoš 2012). Pokud není v textu uvedena citace, vycházejí autoři z výsledků výzkumu shrnutých v nálezové zprávě (Duffek a kol. 2017).

Počátecko patř́i k velmi málo poznaným regionům a odkryv daného rozsahu představoval výjimečnou př́iležitost nahlédnout do archeologického a historického vývoje města. Odhaleny byly situace související se založením města v druhé polovině 13. století a s jeho provozem ve vrcholném a pozdním středověku, většina archeologických prací se však týkala struktur 16.19. století. K nejstarším situacím náleží zahloubený suterén domu 0518, zdokumentovaný před čp. 5-6, jehož požárový zánik datujeme k přelomu 13. a 14. století. Rozborem keramického materiálu z objektu 0518 se zabývá kapitola 3 . Hlavní těžiště výzkumu se nacházelo v okolí kostela sv. Jana Křtitele, v prostoru bývalého městského hřbitova, odkud bylo při obou výzkumech vyzdviženo 228 koster jedinců středověkého až novověkého stáří, které byly podrobeny antropologické analýze. Výzkumem byla potvrzena přítomnost doposud neznámé kamenné hřbitovní zdi a objektu interpretovaného jako márnice. V blízkosti kostela byly prováděny sondáže směřující k odhalení jeho nejstarších stavebních fází. Další archeologické situace souvisely s obléháním města a s ničivými požáry $\mathrm{v}$ letech 1653-1821 (viz kapitola 2). V ploše náměstí se podařilo 
odhalit četné vyrovnávky vytvořené při přestavbách vyhořelých měštanských domů. Nejmladší archeologické situace spojujeme s razantními úpravami náměstí na počátku 19. století, kdy došlo k likvidaci hřbitovního okrsku, revitalizaci náměstí a uzavření výše zmiňovaných struktur kamennou zádlažbou.

\section{Historie města Počátky}

Okolí Počátek bylo trvale osídleno nejdříve na přelomu 12. a 13. století. Stopy lidské př́itomnosti v pravěku a starověku jsou pouze ojedinělé: nález mincí z doby římské, stříbrný denár císaře Marka Aurelia nalezený ve Vesci u Počátek (139-161) a mince tzv. městské ražby nalezená v lese u Lázní sv. Kateřiny (asi 330-346; Hejhal 2012, 19). Počátky vyrostly na staré cestě spojující Jihlavu s Jindřichovým Hradcem pravděpodobně postupným rozšířením původní osady. Studium starších dějin Počátek komplikuje nedostatek pramenů způsobený požárem roku 1821, který zasáhl radnici i kostel a zničil velkou část písemností města a děkanství (Slavíčková 1993; Holub-Krčilová-Martínek 2009).

Území na severozápadě směrem od Černovic přes Kamenici nad Lipou k Horní Cerekvi kolonizoval rod Benešoviců a okolí vrchu Javořice na jihovýchodě s hradem Štamberk (Štemberk) rod Šternberků (Kuča 2002, 273). Ve 13. století se Počátecko nacházelo mezi biskupským Pelhřimovskem a Jindřichohradeckem pánů z Hradce. Formulář Tobiáše z Bechyně udává, že v období sporů mezi Vítkovci a pražským biskupem se oblast stala obětí plenění. List datovaný mezi roky 1285-1290, který je zároveň první dochovanou zmínkou o Počátkách, ${ }^{1}$ však neříká, o jaký typ sídla se tehdy jednalo (Formulář, 124 č. 155). V roce 1303 bylo na počáteckém statku (bonum) zapsáno věno Berty, druhé manželky Vítka ze Švábenic (RBM II, 852 č. 1982). V letech 1356-1358 se na Počátkách uvádí Štěpán z Březnice, který vlastnil větší panství na moravském území s městem Třešt' a hrady Štamberk a Janštejn (MZD Brno III, 26-39 č. 118, 157, 398, 464). Poté držel Počátky Jan z Hardeka, ${ }^{2}$ purkrabí magdeburský a pán na Kozí, který je 8. záŕí 1389 prodal Jindřichovi III. z Hradce i se všemi užitky za 687 kop grošů pražských (SOA Třeboň, RA z Hradce; RBMV III, 99 č. 221).

Počátky se tak dostaly do majetku pánů z Hradce, nejprve jako součást jindřichohradeckého dominia, po roce 1564, kdy vrchnost znovu získala Žirovnici, byly připojovány spíše k žirovnickému panství (SOA Třeboň, VS Žirovnice). Není zřejmé, kdy Počátky získaly městská práva, nicméně do rukou pánů $\mathrm{z}$ Hradce již přešly jako město. Spolu s dalšími hradeckými statky přešly sňatkem poslední př́slušnice rodu Lucie Otýlie roku 1604 Slavatům. V roce 1693 je opět díky sňatku převzali Šternberkové, kteří byli zároveň poslední zdejší vrchností, jež Počátky spravovala do roku 1850. Zůstaly jediným městem žirovnického panství, přičemž v roce 1792 zde byl ustaven regulovaný magistrát.

Fara u kostela sv. Jana Křtitele je potvrzena v zápisech konfirmačních knih z 50. let 14. století (LS I/1, 88, 101, 106). Církevní správa značně utrpěla v reformačním období, rekatolizace ale proběhla velmi rychle a důsledně. Již v roce 1629 mohla Lucie Otýlie Slavatová z Hradce Počáteckým jako odměnu za opětovné přijetí katolické víry udělit právo vaření a šenkování piva uvnitř hradeb (SOkA Pelhřimov, AM Počátky c). Soupis obyvatelstva podle víry z roku 1651 slovy jindřichohradeckého hejtmana pouze dosvědčuje úplnou rekatolizaci panství, jež se zdařila mimo jiné díky úsilí členů jezuitské koleje (Soupis, 190-191). Od roku 1556 se v Počátkách pořádaly tř́i jarmarky ročně (SOkA Pelhřimov, AM Počátky b), o dvě stě let později Marie Terezie povolila pořádání týdenních trhů s předivem a plátnem (SOkA Pelhřimov, AM Počátky f).

V poslední čtvrtině 17. století byla fara povýšena na děkanství. ${ }^{3}$ Církevní správu od roku 1594 až do zrušení řádu v roce 1773 vykonávali jindřichohradečtí jezuité, poté přešel farní kostel pod patronát c. k. studijního fondu. V druhé polovině 90 . let 16 . století za městem vyrostl

\footnotetext{
1 Tomáš Zapletal (1941) uvádí v současné době neověřitelné doklady o církevní správě k letům 1273 a 1303.

2 Podle Augusta Sedláčka držel Jan z Hardeka Počátky od roku 1368 (Ottův slovník naučný, heslo z Hardeka).

3 Podle Pamětní knihy počáteckého děkanství získal děkanský titul již Vít Bernard Loutkovský, který zde působil v letech $1620-1677$ (SOkA Pelhřimov, DÚ Počátky). Jiné zdroje uvádí povýšení fary na děkanství až roku 1694 za Františka Pavlovského (Šimák 1928).
} 
hřbitovní kostel Božího těla, jehož současná barokní podoba je výsledkem přestavby ukončené roku 1711. Nadále se však pohřbívalo i v prostoru dnešního náměstí, teprve v letech 1802-1804 byl zdejší hřbitov zrušen a definitivně přemístěn ke kostelu Božího těla. Nejpozději na začátku 15. století již bylo město opevněno, ovšem během obléhání husitskými vojsky v letech 1423 a 1425 došlo k takovým škodám, že opevnění musely nahradit provizorní ploty (Kuča 2002, 271). Skutečné kamenné hradby se dvěma věžemi vznikly až někdy před rokem 1504 a významně zasáhly do urbanistického plánu města. Nová vnitřní hradba přet’ala dosavadní náměstí, které se tak zmenšilo na trojúhelník kolem farního kostela, zatímco oddělená část získala charakter pouhého nechráněného předměstí. Vystavění hradeb deklaroval Jindřich IV. v privilegiu

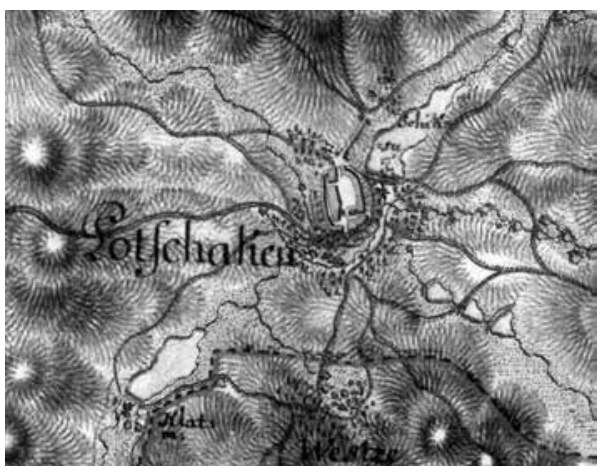

Obr. 1. Počátky, okr. Pelhřimov. Město s okolím na mapě I. vojenského mapování, mapový list č. 236. Zdroj Josephinische Landesaufnahme.

Abb. 1. Počátky, Bezirk Pelhřimov. Stadt und Umland auf einer Karte der I. militärischen Kartierung, Kartenblatt Nr. 236, Quelle Josephinische Landesaufnahme. $\mathrm{z}$ roku 1504, kterým měštanům jako odměnu za jejich statečnost a věrnost udělil právo svobodně odkazovat majetek komukoliv z jeho vlastních poddaných (SOkA Pelhřimov, AM Počátky; CIM IV/3, 76-77 č. 697). Roku 1508 byly tyto výsady rozšířeny i na obyvatele předměstí (SOkA Pelhřimov, AM Počátky a; CIM IV/3, 139-141 č. 748). Městská správa však už v polovině 17 . století od plnoprávných měšt’anských domů kolem náměstí zřetelně oddělovala usedlosti na Horním a Dolním předměstí, která se rychle rozrůstala (SOkA Pelhřimov, AM Počátkyg).

Vnitřní město poznamenaly tři větší požáry v letech 1653, 1662 a 1821, dvacet pět domů na předměstí vyhořelo roku 1869. Zničující byl především první požár, který přišel krátce po švédském vpádu v roce 1645

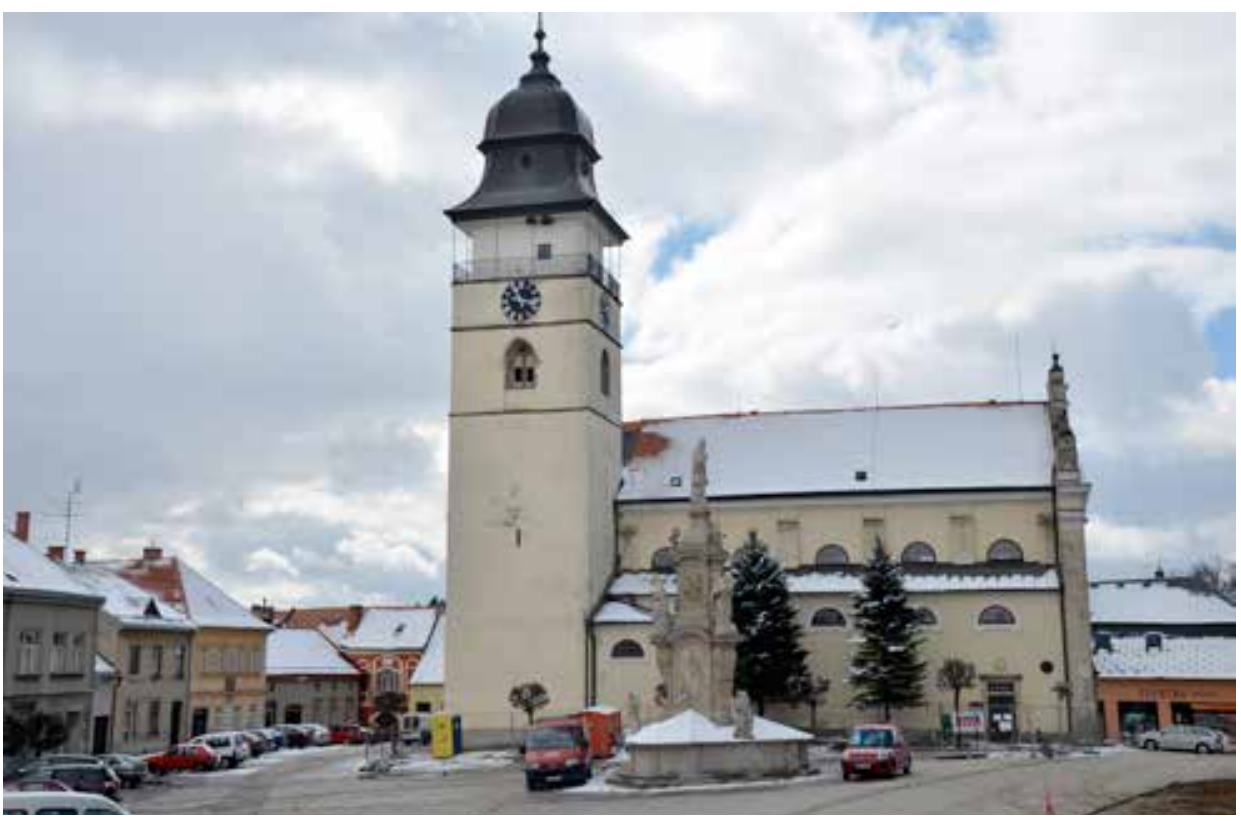

Obr. 2. Počátky, okr. Pelhřimov. Palackého náměstí s kostelem sv. Jana Křtitele. Zdroj Fotoarchiv Archaia Brno, o.p.s. Abb. 2. Počátky, Bezirk Pelhřimov. Palacký-Platz mit Johannes-der-Täufer-Kirche. Quelle Fotoarchiv Archaia Brno, o. p. s. 
a následném znovudobývání města císařskou armádou. Během švédského plenění město přišlo i o část svých privilegií, jejichž platnost krátce po válce zpětně potvrdil Adam Pavel Slavata (SOkA Pelhřimov, AM Počátky d). Škody na branách, městském opevnění a radnici byly patrné ještě koncem 17. století, když se vrchnost roku 1697 ve prospěch jejich opravy vzdala části platů (SOkA Pelhřimov, AM Počátky e). Devastaci města v polovině 17. století ukazuje i berní rula: ve vnitřním městě bylo vedle patnácti osedlých zaznamenáno deset pohořelých a jeden zkažený grunt, z původních sedmi menších usedlostí se udržely jen čtyři. Na předměstích byla situace o něco lepší, snad i proto, že zde byly více zastoupeny menší statky, které se dařilo rychleji obnovit. Celkově bylo v Počátkách napočítáno 124 usedlostí, z toho ale jen 43 osedlých schopných platit daně v plné výši (BR, 183-187).

Tereziánský katastr o 100 let později zmiňuje 164 usedlostí, z nichž polovina byla takřka bez pozemků, a 65 řemeslníků (TK, 360 č. 1422). Koncem 80 . či počátkem 90 . let 18 . století mělo město 231 domů, jejichž obyvatelé se živili především polní prací, předením a výrobou látek (Schaller b. d., 91-94). Postupně se stále více prosazovalo soukenictví a další živnosti s ním spojené. V listopadu 1805 zažilo město okupaci napoleonskými vojsky, požár v roce 1821 zničil 203 domů. Přesto bylo před rokem 1842 ve městě napočítáno 340 čísel popisných a 2561 obyvatel (Sommer 1842, 210-214).

\section{Výsledky archeologického výzkumu}

\section{Suterén dřevohliněné stavby 0518}

V severní části náměstí před domem čp. 6 byl zachycen zahloubený suterén pravděpodobně dřevohliněné nadzemní stavby. Typově podobné stavby byly v posledních desetiletích zkoumány i v jádrech měst Pelhřimov, Humpolec nebo Jihlava (Hejhal-Hrubý 2005, 126-147). Tyto suterény (ve starší literatuře též zemnice či polozemnice) považujeme za sklepní prostory nezděných povrchových staveb nacházejících se nad nimi. Jsou to stavby typické pro druhou polovinu 13. století a již koncem 13. a v průběhu první poloviny 14. století byly nahrazovány zděnými sklepy (Holub a kol. 2005, 44-101).

Suterén 0518 je zatím nejstarší zachycenou archeologickou situací v historickém jádru města Počátky. Jednalo se kvadratický výkop s obdélným půdorysem o rozměrech $5,2 \mathrm{~m}$ ve směru sever-jih a 3,6 m ve směru východ-západ (obr. 3). Výkop byl zahlouben ve svahu pevného rulového podloží v hloubce $0,54-1,12 \mathrm{~m}$. Suterén domu nerespektoval nynější uliční čáru západní fronty domů (čp. 31 - čp. 8) na Palackého náměstí. Jeho jihovýchodní nároží vystupovalo 9,4m před dům čp. 6 (objekt bývalé radnice s renesančním jádrem) a jeho delší osa byla s domem rovnoběžná. Vstupní šíje nebyla zachycena, ale je možné, že se nacházela v části zničené výkopem pro kanalizaci. Stěny výkopu byly př́mé, s ostrým přechodem do dna, na stěnách i podlaze byly patrné traseologické stopy nástrojů, jimiž byl výkop vyhlouben. Relativně ploché dno se svažovalo o několik centimetrů k severovýchodu. Ve vzdálenosti $0,04-0,12 \mathrm{~m}$ od obvodových stěn procházel přibližně $0,2 \mathrm{~m}$ široký žlábek, který byl nejvíce zahlouben v severozápadním rohu suterénu (ca $0,06 \mathrm{~m})$. V žlábku byly opět patrné podélné traseologické stopy po nástroji, jímž byl vykopán. Ve výplni žlábku byly zachyceny části základového trámového věnce, který tvořila zetlelá dřevitá vrstvička s přibližně $0,2 \mathrm{~m}$ dlouhými zuhelnatělými fragmenty trámů. Odebrané vzorky dřeva byly určeny jako jedle, nepodařilo se je bohužel vzhledem ke stavu dochování dendrochronologicky datovat (Kyncl 2016, 1).

Na dně objektu ležel šedý $0,02-0,06$ m mocný podlahový nášlap s malými zlomky uhlíků, mazanice a velmi malými zlomky kamenů. Ve středu podlahy suterénu byl tento podlahový nášlap tvořen až čtyřmi vrstvami stejného charakteru. Zásyp suterénu tvořily v dolní části homogenní hlinito-písčité vrstvy s menším podílem uhlíků a kamenů. Ve střední části zásypu se stř́idaly hlinité vrstvy s vrstvami z velké části tvořenými uhlíky a písčitou hlínou. Situaci uzavíral zásyp velkých kamenů $(0,1 \mathrm{~m}-0,66 \mathrm{~m})$ a písčité hlíny. Svrchní a střední část zásypu obsahovaly z kovových nálezů především kovářské strusky, hřebíky a dvě ramena podkov (Malý 2016, 10). Na jejich bázi se nacházela písčitá vrstva obsahující fragment železného nože a bronzový 
plíšek. Střední zásyp obsahoval několik úlomků plechu z barevného kovu a množství hřebů. Podlahové a komunikační vrstvy objektu 0518 neobsahovaly žádné kovové nálezy.

Z komunikačních vrstev a zánikového horizontu byly odebrány vzorky pro archeobotanickou analýzu. $Z$ výsledků analýzy vyplývá, že soubor rostlinných makrozbytků z podlahových vrstev suterénu 0518 obsahoval zejména zuhelnatělé rostlinné makrozbytky obilnin (žito, pšenice, oves, ječmen, proso) a jejich plevelů. Soubor nezuhelnatělých zbytků pak obsahoval především diaspory sbíraných užitkových rostlin, zejména sbíraného ovoce (ostružiník, jahodník, maliník, líska) a diaspory lokální rumištní vegetace. Druhý zkoumaný vzorek ze zánikové výplně téhož objektu obsahoval unikátní soubor zuhelnatělého lnu s příměsí dalších polních plodin (téměř kompletní soubor vrcholně středověkých obilnin, luštěniny) a typický soubor plevelů lněných polí (linikolní plevele, plevele úhorů, plevele kultur polních plodin na chudých půdách). Antrakologická analýza prokázala exploataci bučin a jedlobučin (v menší míře též lesů sutových a podmáčených poloh) v okolí města. Vysoký podíl světlomilných (sukcesních) dřevin a jehličnanů (zejména smrku) indikuje pokročilé odlesnění okolí města Počátky ve vrcholném středověku (Kočár-Kočárová 2016, 17).

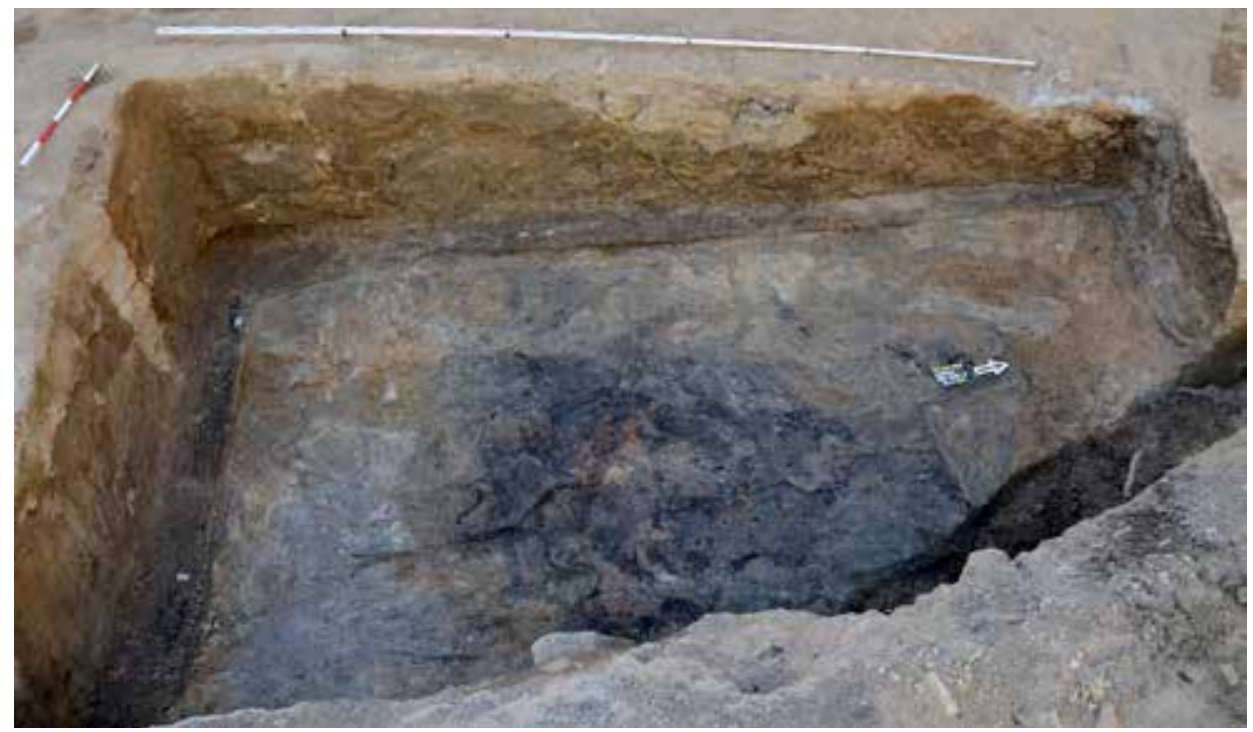

Obr. 3. Počátky, okr. Pelhřimov. Suterén 0518 po exkavaci podlahových komunikačních vrstev, po obvodu výkopu jsou patrné části trámového věnce. Zdroj Fotoarchiv Archaia Brno, o.p.s.

Abb. 3. Počátky, Bezirk Pelhřimov. Souterrain 0518 nach Aushebung der Wegbodenschichten, an den Rändern der Aushebung sind Teile des Balkenkranzes sichtbar. Quelle Fotoarchiv Archaia Brno, o. p.s.

Významnou část výplně objektu tvořil soubor kuchyňské a stolní keramiky čítající 1788 fragmentů. Rámcově jej lze datovat do 13. až začátku 14. století. Složení vysoce fragmentarizovaného souboru nasvědčuje postupnému zaplňování objektu v krátkém období po jeho zániku. Nejvyšší fragmentarizací se vyznačují spodní vrstvy, které lze interpretovat jako nášlapové. Keramika byla pro vyhodnocení rozčleněna do 12 keramických tř́id (dále jen KT; podrobně viz Duffek a kol. 2017).

Hlavní náplň objektu tvoří KT 1-5 (13. až začátek 14. století). Jde o redukčně pálenou keramiku s malým množstvím (KT 4) či vyšším obsahem jemné slídy (KT 3) zčásti s oxidačním přežahem povrchu, v některých případech s lesklým povrchem (snad jde o grafitový nátěr; KT 1,2) a grafitovou keramiku (KT 5). Tvarově v nich převažují hrnce, objeví se fragmenty 
poklic - zvonovitých a kónických, džbánu, kahanu a misky (obr. 4:1-3, 5, 6; 5:1-4). Z okrajů hrnců převažují varianty okrajů střechovitých, vzhůru vytažených klasických a vzhůru vytažených nízkých. Ve více kusech se vyskytly okraje vzhůru vytažené zúžené, plochá okruží, ovalené či přehnuté. Výzdobu keramiky představují různé varianty rýh, žlábků, ojediněle vlnic, případně kombinace těchto prvků. Na dnech se vyskytují značky, ojediněle stopy po výrobní podložce či odříznutí. U části fragmentů bylo možné sledovat výrobní stopy. Ty svědčí o převažující výrobě nádob obtáčením s pomocí tvarování těl nádob $\mathrm{z}$ válků. $\mathrm{K}$ úpravě spodní části nádob bylo

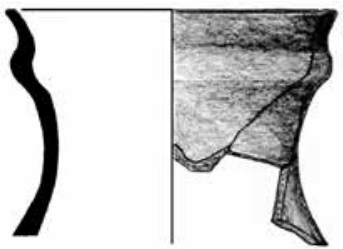

1
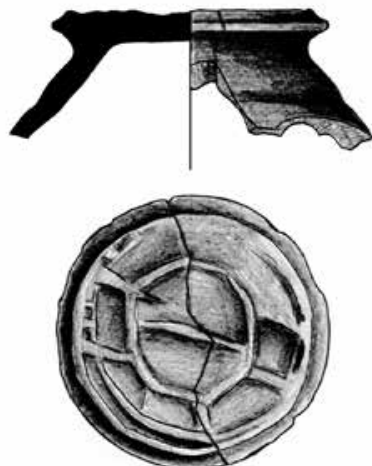

3

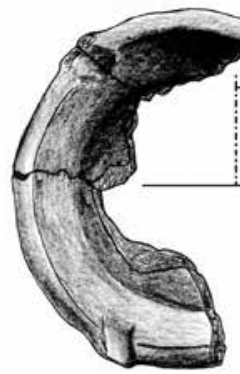

5
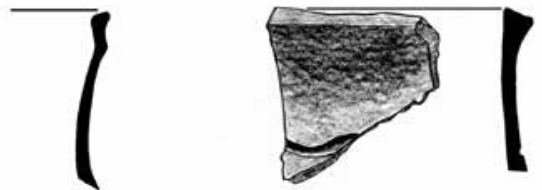

2

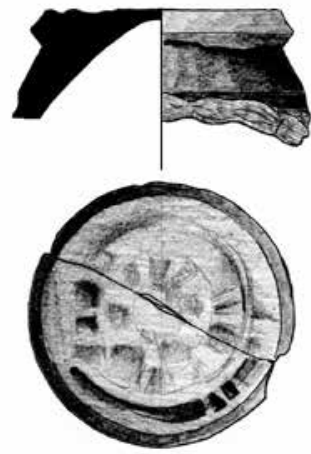

4

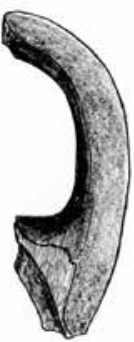

6

Obr. 4. Počátky, okr. Pelhřimov. Kresebná dokumentace keramických tvarů v objektu 0518. 1 - hrdlo džbánu (JiA 112/2015326, 349; vr. 169; KT 1); 2 - fragment misky (JiA 112/2015-334; vr. 171; KT 3); 3 - úchytka poklice se značkou (JiA 112/2015334; vr. 171; KT 3); 4 - úchytka poklice se značkou (JiA 112/2015-334; vr. 173; KT 7); 5 - kahan (JiA 112/2015-330, 350; vr. 194, 202; KT 3); 6 - ucho patrně džbánu (JiA 112/2015-336; vr. 173; KT 3). Kresba E. Bílková-Šámalová, upravil P. Duffek.

Abb. 4. Počátky, Bezirk Pelhřimov. Zeichendokumentation der Keramikformen in Objekt 518. 1 - Krughals (JiA 112/2015326, 349; Schicht 169; Keramikklasse 1); 2 - Fragment einer Schale (JiA 112/2015-334; Schicht 171; Keramikklasse 3); 3 - Deckelgriff mit Marke (JiA 112/2015-334; Schicht 171; Keramikklasse 3); 4 - Deckelgriff mit Marke (JiA 112/2015-334; Schicht 173; Keramikklasse 7); 5 - Öllämpchen (JiA 112/2015-330, 350; Schicht 194, 202; Keramikklasse 3); 6 -offenbar von einem Krug stammender Henkel (JiA 112/2015-336; Schicht 173; Keramikklasse 3; Zeichnung E. Bílková-Š́malová, Bearbeitung P. Duffek. 
v některých případech použito vymačkávání (spodní části nádob mohly být vyrobeny z jednoho kusu hlíny). V souboru se poměrně četně vyskytují zásobnice (KT 10).

Pro nálezovou situaci jsou důležité KT 7 a 8 zastupující sekundárně přepálenou keramiku, která se do objektu dostala patrně s požárovou vrstvou a u některých vrstev tvoří až třetinu keramické výplně (obr. 4:4; obr. 5:5, 6). V několika fragmentech se v horních vrstvách vyskytla slídová keramika (KT 6). Do horních vrstev bylo soustředěno několik fragmentů zakuřované keramiky (KT 9) datovatelné nejdříve na přelom 14. a 15. století. Ojediněle se ve výplni vyskytla novověká keramika (KT 11, KT 12). Její přítomnost může být způsobena porušením části objektu výkopem kanalizace $\mathrm{v}$ roce 2011.

Problémem při porovnání keramického souboru z objektu 0518 s keramikou z okolních regionů je absence dalších publikovaných souborů. Tvarově se nevymyká obvyklému složení pro toto období s naprostou převahou hrnců. Pro keramickou produkci Českomoravské vrchoviny 13. století je typická vysoká variabilita okrajů hrnců s lokálními variantami a typy. Menším podílem „kolonizačních prvkư“, jako jsou ploché poklice, džbány a hrnce s okraji střechovitých a přehnutých tvarů, má keramika z Počátek bliže specifické produkci Českomoravské vrchoviny než produkci jihomoravské (Procházka-Peška 2007, 143-232; Hrubý a kol. 2006, 208-215).

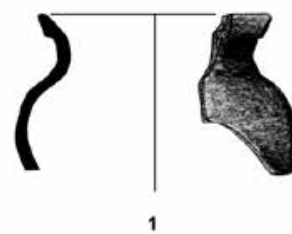

)

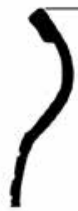

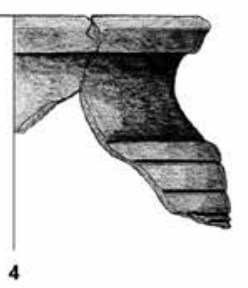

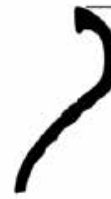

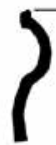

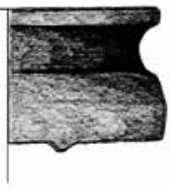

2

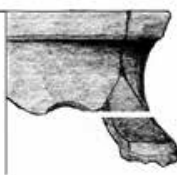

3
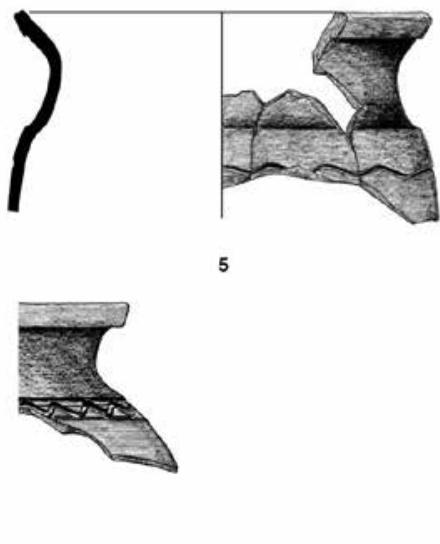

Obr. 5. Počátky, okr. Pelhřimov. Kresebná dokumentace torz hrnců z objektu 0518. 1 - JiA 112/2015-334 (vr. 171; KT 3); 2 - JiA 112/2015-330, 331, 335 (vr. 171, 172, 202, 194, KT 3); 3 - JiA 112/2015-316, 334 (vr. 171, 190; KT 5); 4 - JiA 112/20150336 (vr. 173; KT 3); 5 - JiA 112/2015-0348; 6 - JiA 112/2015-336, 337 (vr. 173, 194; KT 7). Kresba E. Bílková-Ś́malová, upravil P. Duffek.

Abb. 5. Počátky, Bezirk Pelhřimov. Zeichendokumentation der Topftorsos aus Objekt 518. 1 - JiA 112/2015-334 (Schicht 171; Keramikklasse 3); 2 - JiA 112/2015-330, 331, 335 (Schicht 171, 172, 202, 194, Keramikklasse 3); 3 - JiA 112/2015-316, 334 (Schicht 171, 190; Keramikklasse 5); 4 - JiA 112/2015-0336 (Schicht 173; Keramikklasse 3); 5 - JiA 112/2015-0348; 6 JiA 112/2015-336, 337 (Schicht 173, 194; Keramikklasse 7). Zeichung E. Bílková-Šámalová, Bearbeitung P. Duffek. 


\section{Hřbitovní okrsek a stavby u věže kostela}

V okolí kostela sv. Jana Křtitele byl stavebními pracemi zasažen areál zaniklého městského hřbitova. Celkem byly v roce 2015 dokumentovány a vyzvednuty kosterní pozůstatky 193 jedinců, dalších 15 objektů bylo označeno jako pohřeb. Několik desítek jedinců bylo vyzvednuto již v roce 2011. Orientaci bylo možno určit u 186 jedinců. Naprostá většina byla uložena ve směru Z-V (93 pohřbů), druhou nejčastější orientací byl směr S-J (39 pohřbů), přibližně stejný počet měly orientace $\mathrm{JZ}-\mathrm{SV}$ (18 pohřbů) a orientace $\mathrm{J}-\mathrm{S}$ (16 pohřbů). V minimálním počtu byly zastoupeny orientace V-Z (1 pohřeb), SZ-JV (4 pohřby), SSV-JJZ (3 pohřby), ZSZ-VJV (1 pohřeb), SSZ-JJV (2 pohřby), JJV-SSZ (1 pohřeb), ZZS-VVJ (1 pohřeb), JJZ-SSV (1 pohřeb), ZZJ-VVS (5 pohřbů). Většina pohřbů byla situována jižně od kostela a okolo presbytáře. Příčinou hustého uložení pohřbů jižně od lodi kostela byl vysoko vystupující skalní výchoz, pohřby zde ležely těsně vedle sebe a často v několika úrovních. Směrem na jih a východ četnost pohřbů značně klesala (obr. 6). Většina pohřbů byla vlivem stavebních aktivit a v důsledku zvýšené koncentrace v blízkosti skalního výchozu ve větší či menší míře narušená.

Převážná část pohřbů byla nalezena bez zbytků rakve i bez hrobové jámy v promíšené vrstvě 0167 pokrývající celý areál hřbitova. Hrobová jáma byla zachycena u 17 pohřbů a zbytky rakve u šesti pohřbů. Přídavkem pohřbů byly především barokní devocionálie (obr. 7). Zmínit můžeme kř́žz typu Caravaca nebo mosazný kř́žž sv. Benedikta s reliéfní výzdobou tvořenou na lícové straně postavou sv. Benedikta z Nursie a písmeny tzv. Zachariášova požehnání a na rubové straně motivem Benediktova kříže a požehnáním sv. Benedikta. Ve vrstvě 0167 a hrobech $0872,0898,1812,1860,1864,2844$ a 2849 byly hrobovým př́ídavkem růžence - většinou byly nalézány sevřené v rukou zemřelých. Materiálem použitým při výrobě korálků bylo dřevo,

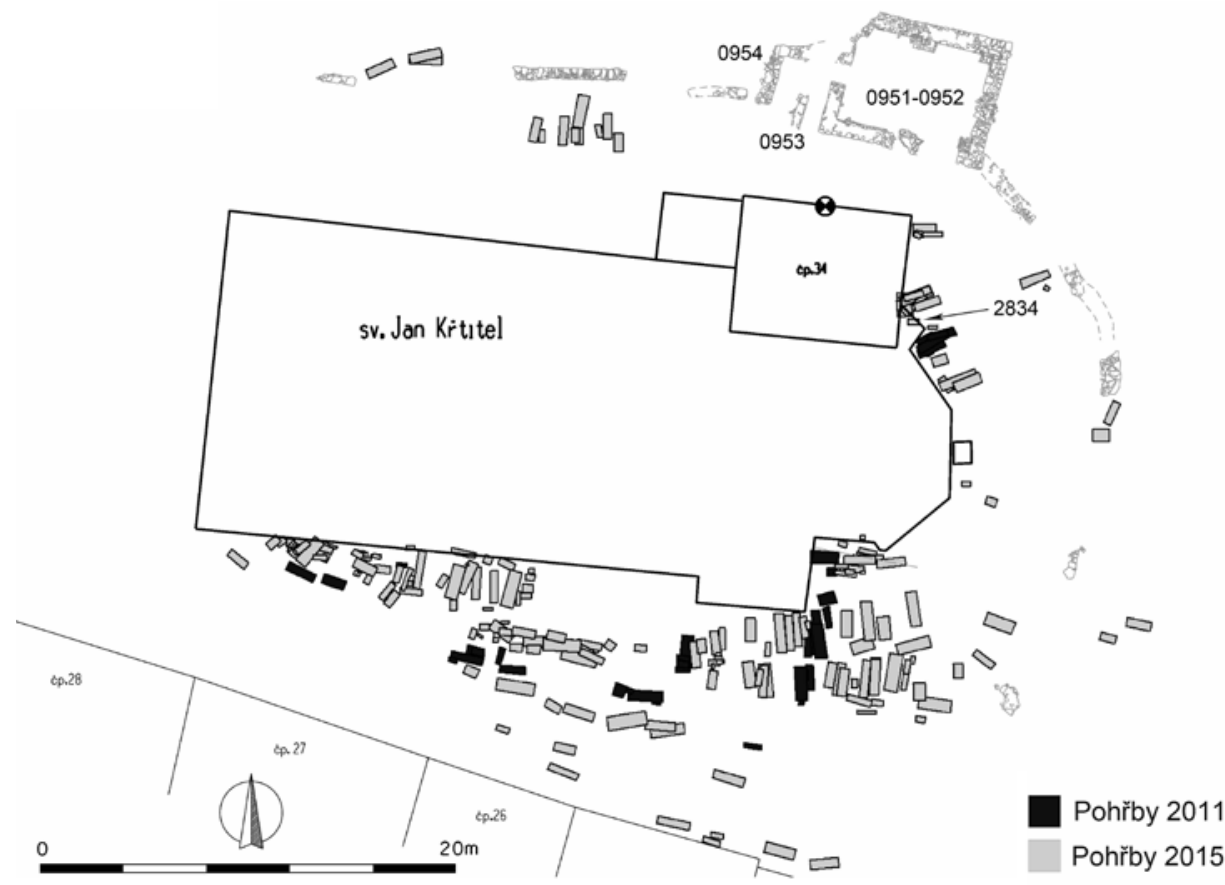

Obr. 6. Počátky, okr. Pelhřimov. Plán hřbitova u kostela sv. Jana Křtitele. Ohradní zed' hřbitova, stavby márnice a pohřby z výzkumů v roce 2011 a 2015. Zdroj Fotoarchiv Archaia Brno, o. p. s.

Abb. 6. Počátky, Bezirk Pelhřimov. Planskizze des Friedhofs an der Johannes-der-Täufer-Kirche. Friedhofsmauer, der Leichenhalle und Bestattungen von den in den Jahren 2011 und 2015 erfolgten Grabungen. Quelle Fotoarchiv Archaia Brno, o.p.s. 
kosti, sklo nebo barevný kov, některé růžence kombinují různé materiály. Růžence z hrobů 0898 a 2843 měly korálky vyrobené ze skla (nazývané také páteříky). Produkce těchto korálků byla doložena i v barokních sklářských hutích na Vysočině v blízkém okolí Počátek (Hrubý a kol. 2009, 491-492). Častými nálezy byly bronzové špendlíky z pohřebních rubášů, háčky, hřeby z rakví, jednoduché prstýnky ze stočeného barevného plechu, zdobené i nezdobené knoflíky. Každodenní provoz v okolí kostela dokládají četné nálezy celých i poškozených hliněných kuliček a také keramické hrací kameny.

Hřbitovní areál o rozloze zhruba $550 \mathrm{~m}^{2}$ byl ohraničen kamennou ohradní zdí, jejíž základ byl zachycen v úsecích východně a severně od kostela. Vně ohradní zdi se nalézalo několik pohřbů východně a větší skupina pohřbů jižně od zdi hřbitova. Orientace pohřbů ve směru západvýchod a jejich poloha těsně u domů jižní strany náměstí by mohla vypovídat o starší středověké části areálu hřbitova, která byla později při změnách zástavby v jižní části náměstí omezena do plochy ohraničené hřbitovní zdí. Severně od věže kostela sv. Jana Křtitele se nacházely základy dvou staveb v superpozici. Sklep novověké stavby se vstupní šíí (konstrukce 0951-0953) porušovala východní část menší stavby 0954 . Obě stavby byly zkoumány plošně, s využitím sondáže do klíčových konstrukčních částí. Zásyp starší stavby konstrukce 0954 a komunikační nášlapy při bázi vstupní šíje obsahovaly keramiku datovanou do 15.-16. století. Zásyp suterénu
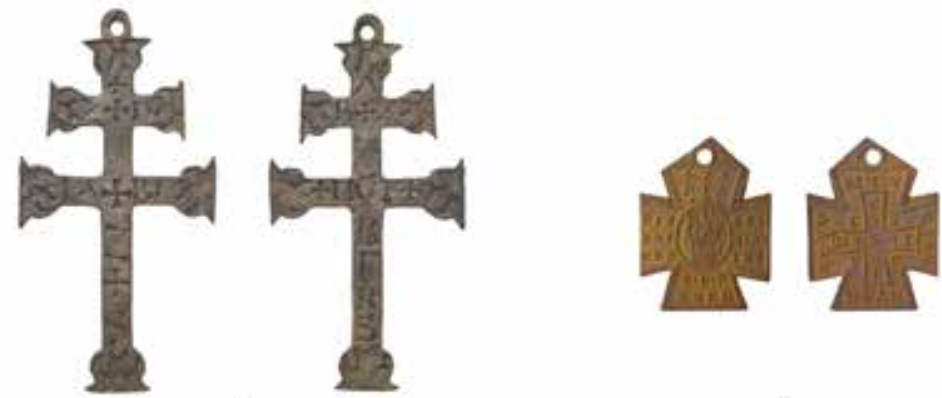

1

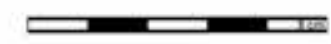

2

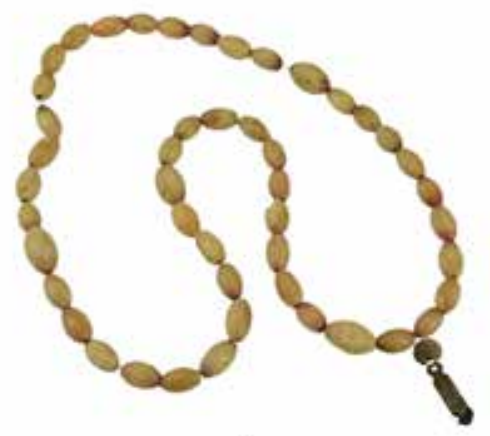

3

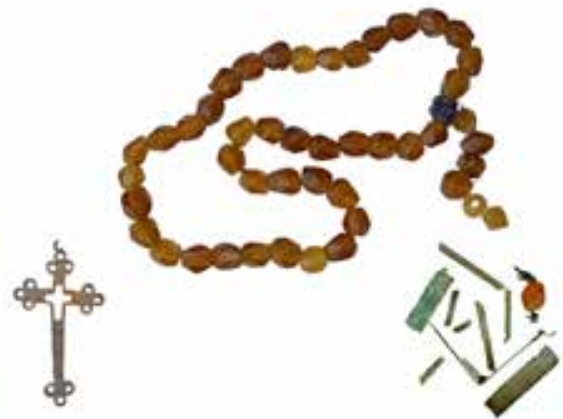

4

Obr. 7. Počátky, okr. Pelhřimov. Fotografická dokumentace vybraných přídavků pohřbů. 1 - dvouramenný kříž typu Caravaca, detektorová prospekce, uloženina 0167; 2 - benediktinský kříž, detektorová prospekce, uloženina $0167 ; 3$ - růženec s kostěnými korálky, závěskem a křížkem z barevného kovu z hrobu 0872; 4 - rủženec s medově hnědými skleněnými fasetovanými korálky (páteříky) a schránkou z barevného kovu z hrobu 0898. Přesná podoba rủženců nebyla zachycena a pro potřeby fotografické dokumentace jsou volně sestaveny. Foto Š. Kochan.

Abb. 7. Počátky, Bezirk Pelhřimov. Fotodokumentation ausgewählter Begräbnisbeigaben: 1 - Doppelkreuz vom Typ Caravaca, Detektorprospektion, Ablagerung 0167; 2 - Benediktinerkreuz, Detektorprospektion, Ablagerung 0167; 3 - Rosenkranz mit Beinperlen, Anhänger und Buntmetallkreuz aus Grab 0872; 4 - Rosenkranz mit kupferbraunen facettierten Glasperlen (Paternosterschnüre) und Kästchen aus Buntmetall aus Grab 0898. Die genaue Form der Rosenkränze wurde nicht erfasst und für den Bedarf der Fotodokumentation frei zusammengestellt. Foto Š. Kochan. 
stavby konstrukce 0951 a vrchní partie zásypu vstupní šíje obsahovaly mladší keramický materiál převážně ze 17.-18. století. Poloha obou staveb v rámci hřbitovního areálu, zakomponování do ohradní zdi hřbitova a vstupní šíje do mladší stavby konstrukce $0951 \mathrm{z}$ areálu hřbitova vede $\mathrm{k}$ interpretaci obou staveb jako starší a mladší budovy s funkcí márnice. K tomuto předběžnému závěru bohužel chybí doklad v historických pramenech. Zánik mladší stavby klademe na počátek 19. století.

\section{Př́istavby a stavební fáze kostela sv. Jana Křtitele}

U jižní lodi a u závěru kostela sv. Jana Křtitele byly zachyceny základy několika přístaveb, které nalezneme v historických mapách, nebo je zmiňují archivní prameny. Byla zachycena jižní oválná přístavba kostela, zobrazená na mapě tržiště města Počátky z roku 1866 (SOkA Pelhřimov, AM Počátky h). Stavba na rozhraní jižní lodi a závěru kostela může souviset se zmínkou o stavbě kobky zedníka Vlacha na jižní straně kostela u presbytáře (Kuča 2002, 271). Při snižování terénu u závěru kostela sv. Jana Křtitele byly odhaleny kamenné základy tř́ dnes již neexistujících opěráků gotického polygonálního závěru kostela i základ jediného dosud stojícího opěráku. Část nadzemního zdiva v místě napojení věže a základů polygonálního závěru kostela bylo i s opěrákem a kamennou průběžnou podokenní římsou pojato do barokní přestavby, která probíhala v letech 1688-1702 (Kuča 2002, 271). Základy dochovaného opěráku překrývaly pohřeb 2834 se zlomkem silnostěnného zlomku keramiky s příměsí grafitu v zásypu hrobu. Tato situace dává podnět k úvaze o využití lokality jako pohřebiště ještě před výstavbou kamenného gotického kostela. Sondáží bylo dokumentováno i napojení konstrukce základů věže k závěru kostela. Stavbu věže můžeme považovat za pozdně gotickou (konec 15. až polovina 16. století) a dodatečně přistavěnou ze severní strany k již stojícímu závěru gotického kostela (Mičan-Musil 1996, 8).

\section{Novověké situace v severní polovině náměstí}

Ke vzniku mladších archeologických situací došlo na náměstí až na sklonku vrcholného středověku. Povrch náměstí nebyl až do 19. století plošně zpevněn dlažbou. Terénní nerovnosti, výmoly, kaluže a jámy, způsobené provozem na náměstí či stavebními úpravami, byly vyrovnávány stavební sutí, odpadem, štěrkem a podobnými materiály. Nacházely se v exponovaných místech před vstupy do měštanských domů po obou stranách náměstí a v prostoru komunikací (obr. 8).

K rozsáhlým úpravám náměstí došlo především po požárech města v 17.-19. století. Z této doby pochází zahloubený kruhový objekt 0520 , zdokumentovaný před současnou radnicí, kde porušoval starší vyrovnávky terénu. Objekt měl průměr $2,8 \mathrm{~m}$ a hloubku $0,4 \mathrm{~m}, \mathrm{v}$ jeho středu se nacházel vypálený blok zeminy, kamenů, zbytků střešní krytiny a cihel. Mimo to se v něm nacházelo relativně velké množství opálených kamenů a kuchyňské a stolní keramiky (obr. 9).

Keramika z objektu 0520 představuje vítaný exkurz do hrnčířské produkce přelomu 16. a 17. století. Zakuřovaná keramika, vypálená do tmavě šedých až černých odstínů zcela převažuje, menšinu souboru tvoří světlé či okrové, oxidačně pálené zboží s vnitřní zelenou až zelenohnědou glazurou. Mezi 575 fragmenty lze rozeznat 8-10 torz nádob, převážně hrnců a hrnců s uchem, ojediněle zvonovitých poklic a misek či trojnohých pánví. Výdutě redukčně pálených hrnců nesou výzdobu rytým žlábkováním, různými druhy radélek, či leštěním. V běžném spektru okruží, ovalených, př̌ehnutých okrajů hrnců se opakovaně objevuje okraj přehnutý, jehož vnější lem je po obvodu pravidelně přimačkáván $k$ hrdlu a tvoří estetické zvlnění. Tento motiv je aplikován na redukční i oxidační zboží. Shodně zdobené zboží i nádoby se zvlněným okrajem bylo nalezeno např́klad v jímce č. 1680 z Pražského hradu, kde je datováno do konce 16. až první poloviny 17. století (Blažková-Vepřeková 2015, 394). Ze zásypu objektu byl mimo keramiky získán také černý peníz Vladislava Jagellonského. Výkop 0520 byl po zániku porušen mladším výkopem, který obsahoval pohřeb psa domácího, přikrytého zásypem drceného křemene (obr. 10). 


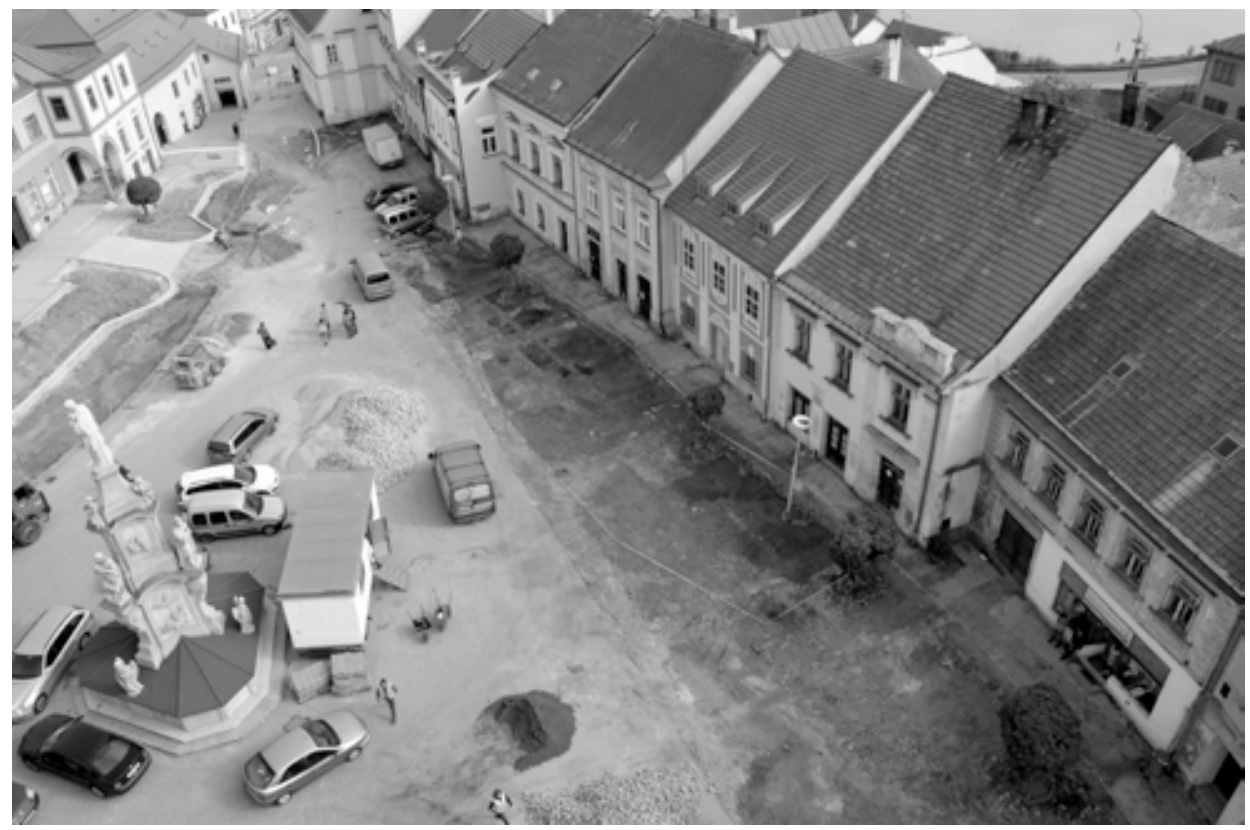

Obr. 8. Počátky, okr. Pelhřimov. Pohled na východní frontu domů z vě̌̌e kostela sv. Jana Křtitele. Před domovními vstupy jsou patrné štěty a vyrovnávkové vrstvy tvořené sutí, propálenými vrstvami a struskou. Zdroj Fotoarchiv Archaia Brno, o.p.s.

Abb. 8. Počátky, Bezirk Pelhřimov. Block auf die Ostfront der Häuser vom Turm der St. Johannes-der-Täufer-Kirche. Vor den Hauseingängen sind aus Bauschutt, Brandschichten und Schlacke bestehende Packlagen und Nivellierschichten sichtbar. Quelle Fotoarchiv Archaia Brno, o.p.s.

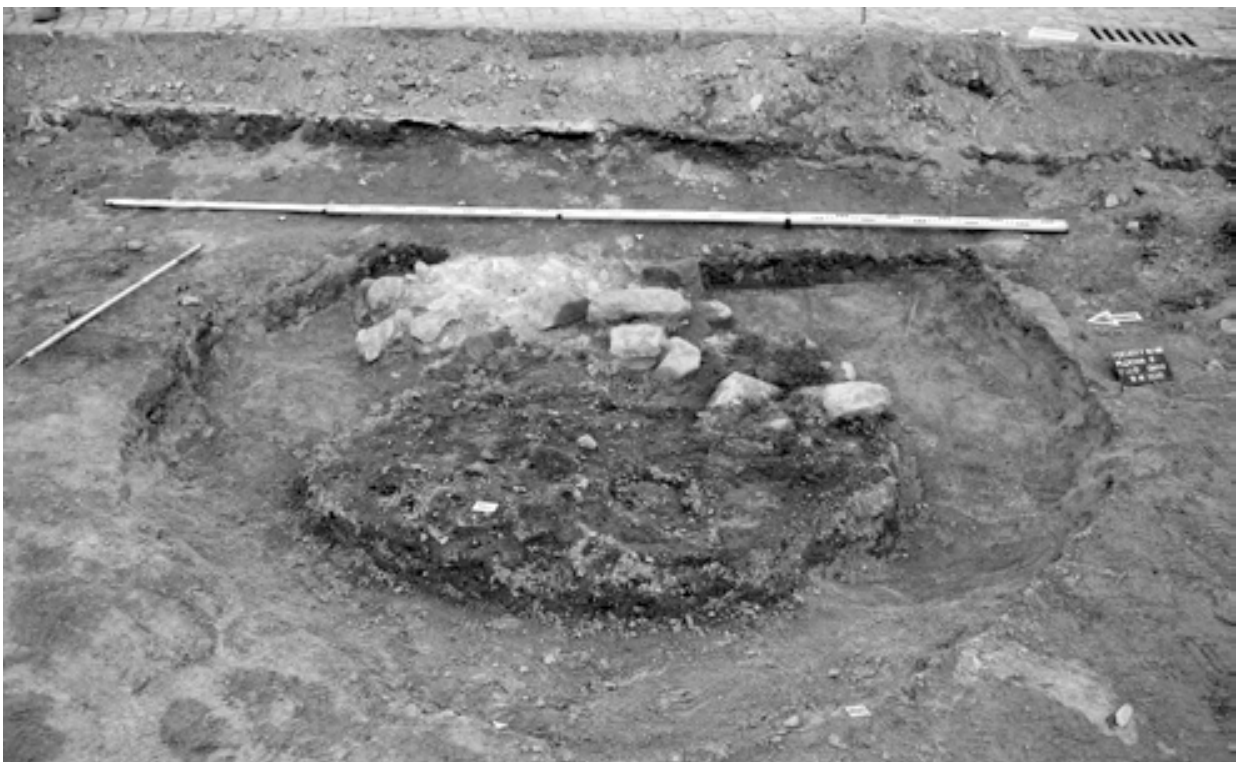

Obr. 9. Počátky, okr. Pelhřimov. Pohled na zahloubený objekt 0520 s propálenou centrální částí. V pozadí patrný zásyp pohřbu psa domácího. Zdroj Fotoarchiv Archaia Brno, o. p.s.

Abb. 9. Počátky, Bezirk Pelhřimov. Blick auf eingetieftes Objekt 0520 mit verbranntem zentralen Teil. Im Hintergrund offenbar die Verfüllung eines Begräbnisses eines Haushundes. Quelle Fotoarchiv Archaia Brno, o. p. s. 


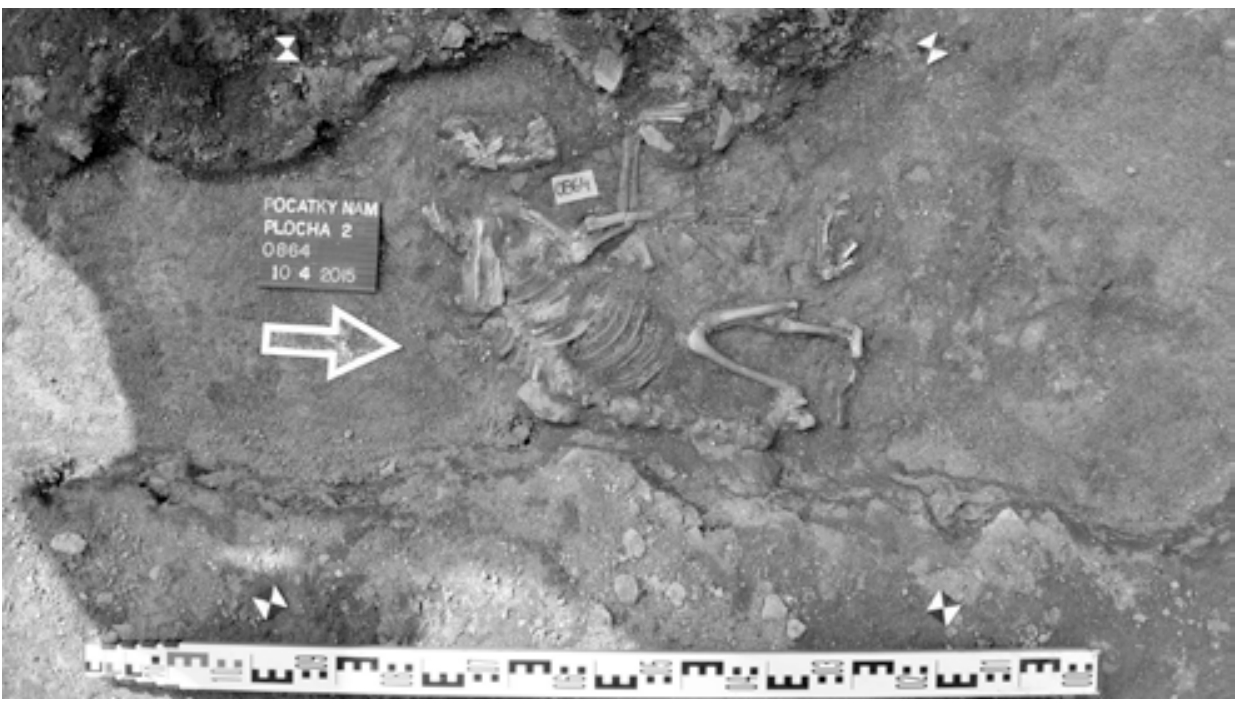

Obr. 10. Počátky, okr. Pelhřimov. Detail pohřbu psa domácího v objektu 0520. Zdroj Fotoarchiv Archaia Brno, o. p.s. Abb. 10. Počátky, Bezirk Pelhřimov. Detail des Begräbnisses eines Haushundes in Objekt 0520. Quelle Fotoarchiv Archaia Brno, o.p.s.

Dalším archeologicky bohatým úsekem byla východní část náměstí, přiléhající k domovní frontě čp. 8-22 (obr. 8). V tomto úseku byly zdokumentovány především kulturní uloženiny, štěty a vyrovnávky, datované od 13. do 17. století. K nejstaršímu horizontu náleží štěty před čp. 15 s keramikou od 13. do 14. století. K rozsáhlému ukládání kulturních vrstev před čp. 13-19 docházelo především v období 14. a 15. století. Pozoruhodný je zejména útržek štětu, vytvořený za pomoci několika stovek zlomků zásobnice, keramiky 15.-16. století a středně velkých kamenů. Poslední etapou vzniku kulturních vrstev před čp. 13-17 bylo období 15.-17. století. Setkáváme se opět se štěty i s vrstvami propálené hlíny a strusek. Méně obvyklé byly zahloubené objekty. Jmenujme především objekt 559 obsahující množství drobných nálezů, keramiky a především reliéfních kachlů, datovaných do 16.-17. století. Převážnou část uvedených stratigrafických jednotek spojujeme s úpravami pochozích povrchů, či s vyrovnáváním terénních nerovností a deponováním odpadu v době rekonstrukcí měšt’anských domů.

Po skončení exkavačních prací byla v prostoru severně od kostela uskutečněna detektorová prospekce $\mathrm{s}$ cílem získat drobné kovové nálezy z již přemístěných a narušených uloženin. Za zmínku stojí zvláště velké množství předmětů osobní potřeby - přezek, zdobených i nezdobených novověkých knoflíků a šperků (prsten s vypadlým kamenem a přívěsek v podobě květiny s bílým a červenými kameny). K osobním předmětům patří jedno kompletní kování dýmky. Nalezeny byly také předměty související s provozem hřbitova - četné svátostky a křižzy, např́iklad svátostka sv. Jana Nepomuckého ve tvaru jazyka. S obchodním ruchem města Počátky lze spojit nálezy olověných plomb, množství středověkých i novověkých mincí a především barokní mincovní závaží o váze jednoho říšského zlatého goldguldenu. S ničivými událostmi a vojenským obléháním města souvisí nálezy olověných kulí a také fragment osmihranné bronzové hlavně pozdně středověké palné zbraně ráže $37 \mathrm{~mm}$.

\section{Antropologická analýza kostrových pozůstatků ze hřbitova v Počátkách z 13.-18. století}

Pohlaví bylo odhadnuto pouze u jedinců, u kterých jsou dostatečně rozvinuté pohlavně dimorfní znaky, tedy u dospělých jedinců a u některých dospívajících. K určení pohlaví byl 
především využit diskriminační program DSP pro pánev (Murail a kol. 2005), dále pak morfometrie kosti pažní a stehenní (Černý 1971) a kosti hlezenní (Novotný 1985). V př́ípadě kosti pažní a stehenní bylo pohlaví hodnoceno na základě tabulek (Černý 1971), a nikoliv podle diskriminačních rovnic (Černý-Komenda 1980), protože výsledky z tabulek téměř ve všech případech korelovaly s výsledky programu DSP, kdežto diskriminační rovnice se často svým výsledkem lišily nejen od programu DSP, ale také v rámci vlastní metody; jedinci byli jednou označováni za muže a jednou za ženy podle různých rozměrů na kosti. Morfoskopické hodnocení lebek (Walrath-Turner-Brůžek 2004) bylo do výsledků zahrnuto pouze výjimečně z důvodu výrazné gracility lebek u studované populace (viz níže), téměř všechny lebky podle této metody byly ženského pohlaví, přestože mnoho z těchto jedinců mělo morfoskopicky výrazně mužskou pánev a program DPS je také označoval jako mužské.

U nedospělých byl biologický věk odhadován podle vývoje a míry prořezání chrupu (Ubelaker 1978; Vlček 1994), maturace kostí a přirůstání epifýz (Ferembach-Schwidetzky-Stloukal 1979; Schaefer-Scheuer-Black 2009) a délky dlouhých kostí (Stloukal-Hanáková 1978; Florkowski-Kozlowski 1996; Schaefer-Scheuer-Black 2009). U dospělých byla hodnocena abraze zubů (Lovejoy 1985) a struktura facies symphysialis (Nemeskéri-Harsányi-Acsádi 1960).

Stanovení výšky postavy bylo odhadnuto ze standardizovaně definovaných (Brauer 1988) metrických hodnot dlouhých kostí pomocí regresních metod Breitingera (1937), Bacha (1965) a Černého a Komendy (1982), dále metodou organické korelace (Sjøvold 1990). V některých případech byly provedeny korekce (Kuželka 1999) při nadhodnocování tělesné výšky. Kvůli slabé korelaci fyziologické délky kosti holenní, výšky postavy u metody organické korelace a Bachovy metody pro určení výšky žen nebyly tyto odhady zohledněny ve výsledcích.

Celkem bylo určeno 228 hlavních jedinců. U dalších 124 částí koster nebylo možné s jistotou říci, zda se jedná o další jedince, nebo o kosti zmíněných hlavních jedinců, proto byly označeny jako příměs. Stejná byla situace v případech dalších 12 hrobů, u nichž se jednalo vždy minimálně o dva jedince, zachovalost jejichž koster byla převážně do $5 \%$; i tyto kosti byly zařazeny do př́íměsi. Z celkového součtu 228 hlavních jedinců jich stupeň zachování mezi $75-100 \%$ mělo pouze šest, ve skupině 50-75\% se nachází 29 prrípadů, interval $25-50 \%$ čítá 62 jedinců a nejvíce, tedy 131 jedinců, je v rozmezí zachovalosti 0-25\% (obr. 11). Nízká zachovalost znemožnila u velké části jedinců stanovení alespoň základních údajů: určení pohlaví a odhad věku a výšky. Velmi často byl povrch kosti ve značném stadiu diageneze, což komplikuje či znemožňuje správné určení patologických procesů. V souboru byly podstatně lépe dochovány kostry z výzkumu z let 2010/2011 (Černoš 2012) než kostry z pozdějšího výzkumu z roku 2015 (Duffek a kol. 2017) - pravděpodobně kvůli tomu, že kostry odkryté při výzkumu v letech 2010/2011 byly uloženy hloub̌eji.

Nejčastějším přírodním činitelem, který narušoval povrch kostí, byly kořeny rostlin, dále pak plísně a styk s kovem (obr. 12). Kostry byly často porušeny sekundární manipulací člověkem: kvůli opakovanému pohřbívání na tatáž místa z důvodu nedostatku prostoru k pohřbívání v okolí kostela a také tramplingem („zdupáváním“), ke kterému přispěla kombinace nízkého uložení pod povrchem a rušnost lokality. Část hřbitova byla odstraněna při jeho rušení, další části pak při novověkých přistavbách kostela a výstavbách inženýrských sítí. Některé kostry byly zasypány vápnem. Tento postup se praktikoval v př́ípadech různých infekcí, kdy se pozůstalí obávali přenosu nákazy. Proto je u těchto jedinců pravděpodobné, že zemřeli na infekční onemocnění (Schotsmans a kol. 2015, 464-479).

Ze zachovalých lebek je většina výrazně gracilních: především nevýrazná glabela i nadočnicové oblouky a ostrá hrana očnice, což v kombinaci s horším dochováním dorzální strany lebky a vysokou fragmentárností značně komplikovalo určování pohlaví podle lebky. Robustní tělesnou stavbu měli na základě svalových úponů jedinci z hrobů 0815, 0817, 0848, 0861 a 2807. Robustní úpony na kostech ruky byly nalezeny v př́ipadě 0847,0817 a 1829 a velmi nápadné úpony Achillovy šlachy na kostrách z hrobů 0875 a 1810. Nejrobustnější kostra patřila muži z hrobu 0847. 
Pohlaví se určovalo u 147 jedinců a podařilo se jej stanovit u 89 případů (obr. 13). Odhad věku lze shrnout následovně: $\mathrm{z}$ celkového součtu 228 jedinců se minimálně 80 jedinců nedožilo dospělosti, ve věku 20 až 40 let zemřelo minimálně dalších 24 lidí a přes 40 let se dožilo alespoň 22 lidí. U zbývajících jedinců se bohužel nepodařilo přesněji odhadnout věk z důvodu špatné zachovalosti koster. Výška byla odhadována u 63 dospělých jedinců. Rozpětí odhadu výšek je 142,5-185,5 cm, přičemž průměrná výška postavy byla odhadnuta podle kosti stehenní na $165 \mathrm{~cm}$ (Sjøvold 1990). Souhrnné výsledky určení pohlaví, odhadu věku a výšky jsou uvedeny v nálezové zprávě (Duffek a kol. 2017).

Z variet vyskytujících se na lebce byly nalezeny vmezeřené kosti (ossiculum suturae lambdoidae) na skeletech z hrobů 0814, 0824, 0867, 0874, 1861 a 2831. Z fragmentu nerozpoznatelný šev, obsahující vmezeřenou kost, byl dále u hrobu 1870 a jako pozůstatek nesrostlé kosti čelní se zachoval šev (sutura metopica) u jedinců z hrobů 0888 a 2800 . V kostech temenních se běžně vyskytují otvory (foramina parietalia), avšak u hrobů 1807 a 1867 dosahují výrazných nadprůměrných rozměrů. Výrazný torus palatinus na tvrdém patře horní čelisti byl objeven na skeletu z hrobu 0876. K nalezeným varietám chrupu patří mesiorotované zuby (bukálním hrbolkem ke střední čáře) z hrobů 0702 a 1836, tuberculum carabelli na první levé horní stoličce (zub 26) u hrobu 1873 a hojně se vyskytují tříhrbolkové druhé horní stoličky (zuby 17, 27; z hrobů 0702, 0867, 0868, 1811, 1816, 1831, 1833, 1848, 1896, 1898, 2814) a šestihrbolkové stoličky (hroby 0702, 0836), u některých z těchto jedinců (hroby 0836 a 0823) se projevuje i nestandardní/opožděný růst některých zubů.

Z postkraniálních variet byla nalezena sakralizace lumbálního obratle (hroby 1843b a 2832). Nesrostlá hrudní kost složená z více sternebrae (hroby 0804,0825 a 0831 ), u hrobu 0825 je rovněž patrný otvor v rukojeti sterna (fenestractio manubrium sterni). U čtyř ženských koster (hroby 0824, 0870, 0871.2 a 1864) se na kosti pažní nalézá otvor (foramen supratrochleare). Přídatný otvor na př́ičném výběžku krčního obratle (foramen processus transversi partitum) byl objeven u hrobu 1833. V jednu spojená přední a prostřední kloubní plocha mezi kostí hlezenní a patní (facies articularis talaris et calcanea anterior et media communis) se nalezla u hrobů 1859,1883 a v př́iměsi hrobu 2809. Dále se vyskytla přídatná kloubní ploška na levé kosti měsíčité (hrob 2835) a pouze jedna kloubní plocha mezi III. a IV. kostí záprstní (hrob 2834).

Patologické projevy na osteologickém materiálu budou předmětem dalšího výzkumu. Předběžně lze říci, že nejčastěji pozorované patologické změny jsou především ty spojované s vyšším věkem, jako jsou např́íklad osteoartritické změny, osteofytické výrustky a srůst kostí. Nalezly se také změny, jako je např́klad cribra orbitalia a hypoplazie zubní skloviny, které mohly být způsobeny nedostatkem živin ve stravě či bakteriálním a virovým onemocněním s vážnějším průběhem. Dále se vyskytovaly zhojené zlomeniny a patologie chrupu, jako např́klad zubní kaz, zubní kámen a již zmíněná hypoplazie zubní skloviny (obr. 14).

Tato část článku vznikla za podpory specifického vysokoškolského výzkumu č. MUNI/A/1279/2016, kterou poskytlo MŠMT. Za cenné rady bychom na tomto místě rádi poděkovali především doc. Mgr. Sandře Sázelové, Ph.D., dále pak RNDr. Robinu Pěničkovi, Ph.D., a Mgr. Martinu Čutovi, Ph.D. Za pomoc se zpracováním části souboru patří náš dík Mgr. Radce Šmídové a Mgr. Lence Jurkovičové.

\section{Diskuse a závěr}

Záchranný archeologický výzkum při rekonstrukci Palackého náměstí v Počátkách přinesl široké spektrum informací o vývoji a historii města ve středověku a novověku. K nejstarším situacím náleží zahloubený suterén pravděpodobně dřevohliněné nadzemní stavby, datované do druhé poloviny 13. století, zachycený v severní části náměstí před domem čp. 6 . Suterén 0518 představuje vůbec nejstarší zachycenou archeologickou situaci ve městě Počátky. Podobné stavby byly v posledních desetiletích zkoumány i v jádrech měst Pelhřimov, Humpolec nebo Jihlava, jsou typické pro druhou polovinu 13. století a již koncem 13. a v průběhu první poloviny 


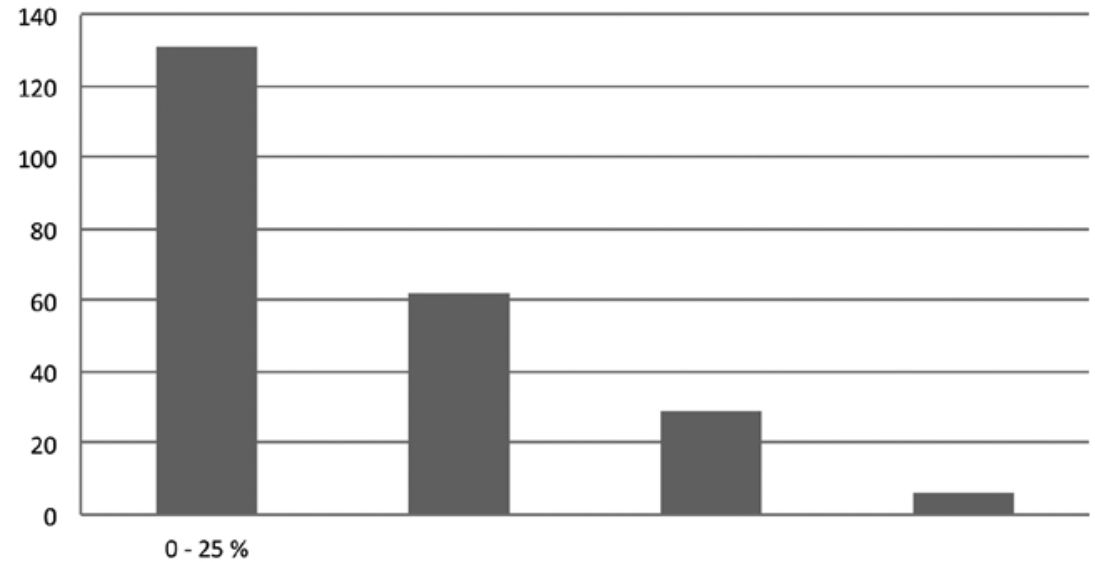

Obr. 11. Počátky, okr. Pelhřimov. Procentuální zachovalost skeletů.

Abb. 11. Počátky, Bezirk Pelhřimov. Prozentuale Erhaltung der Skelette.

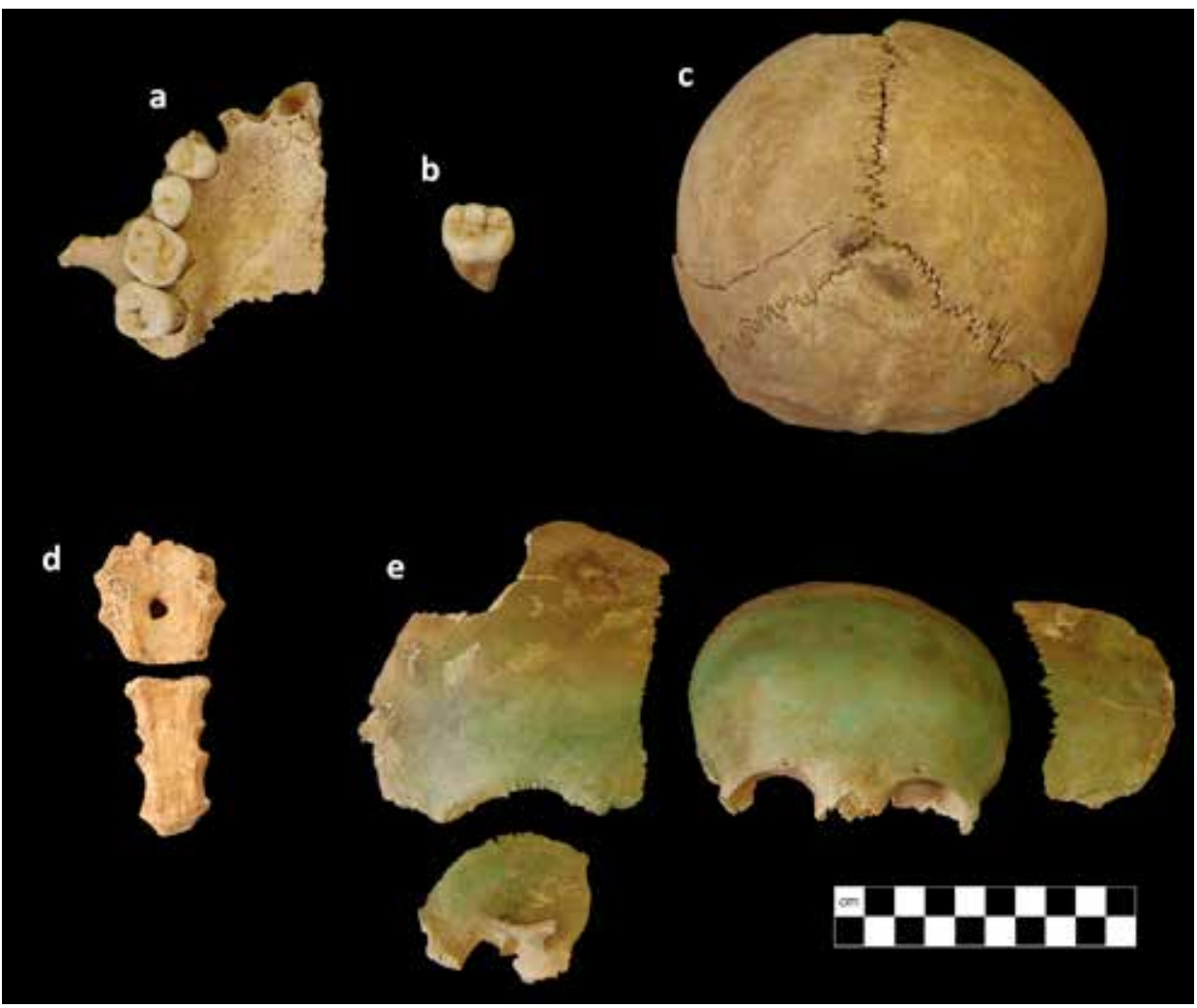

Obr. 12. Počátky, okr. Pelhřimov. Variety a změny způsobené tafonomickými procesy. a - mesiorotace druhého třenového zubu; b - šestihrbolková třetí stolička; c - ossiculum suturae lambdoidae; d-fenestractio manubrium sterni; e - zelené zbarvení způsobené stykem s kovem. Foto $M$. Prachařová a kol.

Abb. 12. Počátky, Bezirk Pelhřimov. Durch taphonomische Prozesse verursachte Varietäten und Veränderungen. a - Verdrehung des zweiten Backenzahnes; $\mathbf{b}$ - sechshöckriger dritter Backenzahn; $\mathbf{c}$ - ossiculum suturae lambdoidae; d - fenestractio manubrium sterni; e - durch Metallkontakt verursachte Grünfärbung. Foto M. Prachařová et al. 


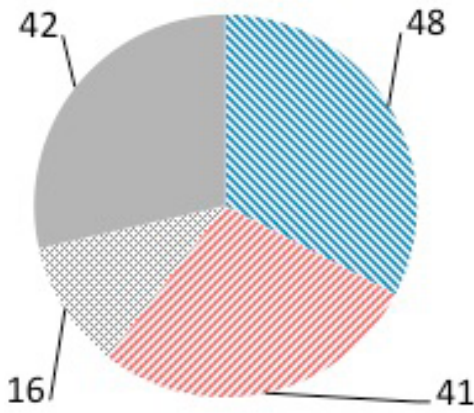

N Muži

\section{Ženy}

$x$

\section{Indiferentní}

Neurčitelné

Obr. 13. Počátky, okr. Pelhřimov. Výsledky určování pohlaví.

Abb. 13. Počátky, Bezirk Pelhřimov. Ergebnisse der Geschlechtsbestimmung.

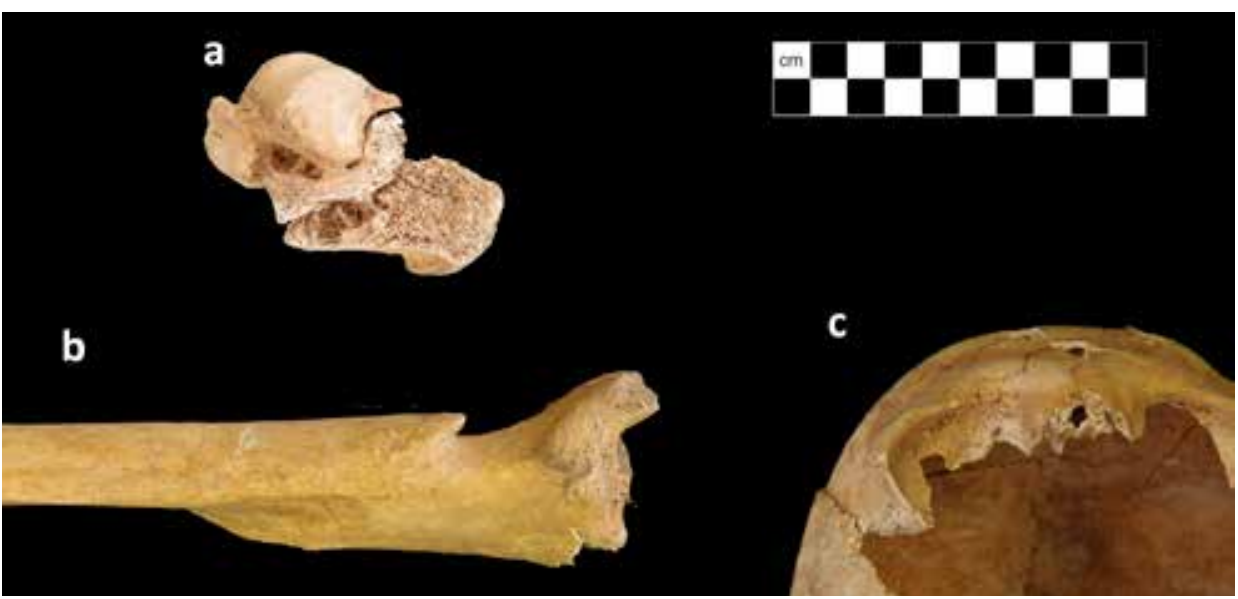

Obr. 14. Počátky, okr. Pelhřimov. Patologické procesy. a - srůst kosti hlezenní a patní; b - srostlá zlomenina kosti holenní; c-cribra orbitalia. Foto M. Prachařová a kol.

Abb. 14. Počátky, Bezirk Pelhřimov. Pathologische Prozesse. a - Verwachsung des Sprunggelenk- und Fersenknochens; b - verwachsener Kniebeinknochen; c - cribra orbitalia. Foto M. Prachařová et al.

14. století mizí. Objekt 0518 přinesl zásadní informace k podobě nezděné architektury, keramické produkce a využití krajiny v okolí města Počátky na přelomu 13. a 14. století.

Na základě vlastností keramického souboru lze spodní vrstvy v objektu 0518 interpretovat jako nášlapové, ostatní představují zásypy objektu. Převažující keramickou náplň objektu lze datovat do druhé poloviny 13. až počátku 14. století. Tvarově dominují hrnce, objeví se fragmenty poklic, džbánu, kahanu a misky. Mezi okraji hrnců převažují vzhůru vytažené, střechovité a vzhůru vytažené nízké, početněji jsou zastoupeny okraje vzhůru vytažené nahoře zúžené a plochá okruží, pouze několika kusy jsou zastoupeny okraje ovalené, přehnuté, vodorovně vyložené a jednoduché vyhnuté. Výzdobu nádob představují rýhy, žlábky či vlnice, případně jejich kombinace, ojediněle vrypy. Na dnech nádob či úchytkách poklic se vyskytují značky. Většina fragmentů, u kterých bylo možné určit způsob výroby, nesla stopy po obtáčení. V celém objektu se vyskytovaly fragmenty zásobnic. Část výplně tvořila přepálená keramika. Archeologický výzkum přinesl nové poznatky k historii i stavebnímu vývoji kostela sv. Jana Křtitele. Bylo zdokumentováno několik zaniklých přístaveb kostela i gotické opěráky staršího středověkého presbytáře, který byl výrazně přestavěn po požáru v roce 1662 . V prostoru presbytáře 
byly odkryty hroby, které se jednoznačně nacházely stratigraficky pod gotickými opěráky, nebo byly stavbou presbytáře poškozeny. Lze tedy uvažovat o tom, že kostelu současné velikosti předcházela $\mathrm{v}$ době počátků města menší sakrální stavba obklopená hřbitovním okrskem, později poškozeným výstavbou.

V prostoru okolo kostela byl stavebními pracemi zasažen areál zaniklého městského hřbitova. Na základě orientace hrobů a jejich výbavy předpokládáme několik etap ukládání zemřelých od vrcholného středověku do začátku 19. století. Hřbitovní okrsek byl v období středověku a novověku vymezen kamennou zdí, nicméně některé hroby se nacházely mimo něj. Lze předpokládat, že by se mohlo jednat o pohřby starší, předcházející výstavbě hřbitovní zdi.

Výsledky antropologické analýzy vyzvednutých jedinců odpovídají stavu zachování koster. Z výše uvedeného vyplývá, že pouze $26 \%$ populace se nedožilo dospělosti, avšak toto číslo je pravděpodobně zkresleno nedochováním koster malých dětí. Jinak se toto pohřebiště skladbou populace s poměrem pohlaví $1: 1,17(\check{Z}: M)$, průměrnou výškou postavy $165 \mathrm{~cm}$, ani varietami a patologickými procesy nijak zvlášt' nevymyká podobným, srovnatelně datovaným pohřebištím na území Moravy (srov. Drozdová 1998; Živný 2010). Na základě zkoumaných patologických procesů byla zjištěna častá přítomnost stresu v dětství. Tímto stresem je míněn např́íklad nedostatek důležitých živin ve stravě nebo vážné virové či bakteriální onemocnění. Kostry povětšinou vykazovaly známky značného opotřebení, a to i u relativně mladých jedinců, což vypovídá o velké fyzické námaze $v$ průběhu života. A v prŕípadě úrazu či nemoci se těmto lidem nedostávalo způsobů léčení na prŕíliš vysoké úrovni; toto lze pozorovat naprríklad v podobě křivě srostlých zlomenin, častých zánětů a zubů, po nichž zubní kaz zanechal pouze kořeny.

Na severní ploše náměstí byly kromě suterénu 0518 zdokumentovány v menším množství pozdně středověké uloženiny a štěty. $V$ průběhu novověku, patrně z důvodu požárů města byly na náměstí v rychlém sledu deponovány vyrovnávkové vrstvy obsahující domácí odpad, strusku, sut' a požárové vrstvy, vzniklé destrukcí měštanských domů, tyto stopově obsahovaly také pozdně středověký materiál. Celou situaci náměstí zakrýval kufr novověké kamenné dlažby, vybudované na počátku 19. století př́i rozsáhlé revitalizaci.

Studie přináší zásadní informace o dějinách města Počátek. Interdisciplinární přesah umožnil doplnit výsledky záchranného archeologického výzkumu o analýzu archivních pramenů, palynologické a antrakologické rozbory pro nejstarší nálezové situace a především o antropologickou analýzu kosterních pozůstatků z výzkumu bývalého městského hřbitova.

\section{Prameny}

SOA Třeboň, RA z Hradce: Státní oblastní archiv Třeboň - oddělení Jindřichův Hradec, Rodinný archiv pánů z Hradce, inv. č. 35 , sign. 43.

SOA Třeboň, VS Žirovnice: Státní oblastní archiv Třeboň - oddělení Jindřichův Hradec, Velkostatek Žirovnice 1651-1918.

SOkA Pelhřimov, AM Počátky: Moravský zemský archiv Brno - Státní okresní archiv Pelhřimov, Archiv města Počátky, inv. č. 1 , listina č. 1 .

SOkA Pelhřimov, AM Počátky a: Moravský zemský archiv Brno - Státní okresní archiv Pelhřimov, Archiv města Počátky, inv. č. 2, listina č. 2.

SOkA Pelhřimov, AM Počátky b: Moravský zemský archiv Brno - Státní okresní archiv Pelhřimov, Archiv města Počátky, inv. č. 6 , listina č. 6 .

SOkA Pelhřimov, AM Počátky c: Moravský zemský archiv Brno - Státní okresní archiv Pelhřimov, Archiv města Počátky, inv. č. 10, listina č. 10 (Lucie Otýlie Slavatová z Hradce, 1629).

SOkA Pelhřimov, AM Počátky d: Moravský zemský archiv Brno - Státní okresní archiv Pelhřimov, Archiv města Počátky, inv. č. 12, listina č. 12 (Adam Pavel Slavata, 1653).

SOkA Pelhřimov, AM Počátky e: Moravský zemský archiv Brno - Státní okresní archiv Pelhřimov, Archiv města Počátky, inv. č. 16, listina č. 16 (Adolf Vratislav ze Šternberka a Anna Lucie Otýlie, 1697).

SOkA Pelhřimov, AM Počátky f: Moravský zemský archiv Brno - Státní okresní archiv Pelhřimov, Archiv města Počátky, inv. č. 18, listina č. 18 (Marie Terezie, 1756).

SOkA Pelhřimov, AM Počátky g: Moravský zemský archiv Brno - Státní okresní archiv Pelhřimov, Archiv města Počátky, inv. č. 83-87, knihy č. 105-109 (pozemkové knihy z let 1651-1696 a 1696-1789). 
SOkA Pelhřimov, AM Počátky h: Moravský zemský archiv Brno - Státní okresní archiv Pelhřimov, Archiv města Počátky, inv. č. 1852-1853, mapa č. 11-12 (mapa tržiště města Počátky z roku 1866).

SOkA Pelhřimov, DÚ Počátky: Moravský zemský archiv Brno - Státní okresní archiv Pelhřimov, Děkanský úřad Počátky, inv. č. 1, kniha č. 1 (Pamětní kniha děkanství v Počátkách, 1796-1949).

BR: Berní rula 4. Kraj Bechyňský I (Čadková, I.-Zahradníková, M., edd.). Praha 2013.

CIM: Codex iuris municipalis Regni Bohemiae IV/3, 1501-1526 (Haas, A., ed.). Praha 1961.

Formulář: Formulář biskupa Tobiáše z Bechyně, 1279-1296 (Novák, J. B., ed.). Praha 1903.

LS I/1: Libri confirmationum I/1, 1354-1362 (Tingl, F. A., ed.). Pragae 1867.

MZD Brno III: Die Landtafel des Markgrafthumes Mähren, Brünner Cuda III, 1348-1466 (Chytil, J.-Chlumecký, P.-Demuth, K.-Wolfskron, A., edd.). Brün 1856.

RBM II: Regesta diplomatica nec non epistolaria Bohemiae et Moraviae II, 1253-1310 (Emler, J., ed.). Pragae 1882.

RBMV III: Regesta Bohemiae et Moraviae aetatis Venceslai IV. III. Fontes archivi publici Trebonensis (Kopičková, B., ed.). Praha 1977.

SCHALLER, J., b. d.: Topographie des Königreichs Böhmen. Vierzehnter Theil, Taborer Kreis. Prag.

SOMMER, J. G., 1842: Das Königreich Böhmen. Taborer Kreis. Prag.

Soupis: Soupis poddaných podle víry z roku 1651, Bechyňsko (Sedláčková, H.-Kokošková, Z.-Zahradníková, M., edd.). Praha 1997.

TK: Tereziánský katastr český II. Rustikál (kraje K-Ž) (Chalupa, A.-Lišková, M.-Nuhlíček, J.-Rajtoral, F., edd.). Praha 1966.

\section{Literatura}

BACH, H., 1965: Zur Berechnung der Körperhöhe aus den langen Gliedmaßenknochen weiblicher Skelette, Anthropologischer Anzeiger 29, 12-21.

BLAŽKOVÁ, G.-VEPŘEKOVÁ, J., 2015: Nálezy hmotné kultury z renesančních odpadních jímek z Pražského hradu. Díl I. Katalog. Castrum Pragense 13. Praha.

BRÄUER, G., 1988: Osteometrie. In: Anthropologie. Handbuch der vergleichenden Biologie des Menschen. 4. Auflage des Lehrbuchs der Antropologie begründet von Rudolf Martin (Knußmann, R., ed.), 160-232. Stuttgart - Jena - New York.

BREITINGER, E., 1937: Zur Berechnung der Körperhöhe aus den langen Gliedmaßenknochen, Anthropologischer Anzeiger 14, 249-274.

ČERNOŠ, Š., 2012: Rekonstrukce ČOV a kanalizace Vesce a Palackého náměstí, nálezová zpráva, rkp. ulož. v Archaia Brno, o.p.s., č. A062/2010.

ČERNÝ, M., 1971: Určování pohlaví podle postkraniálního skeletu. In: Symposium o určování stáří a pohlaví jedince na základě studia kostry (Vlček, E., ed.), 46-62. Praha.

ČERNÝ, M.-KOMENDA, S., 1980: Sexual Diagnosis by the Measurements of Humerus and Femur. In: Sborník prací pedagogické fakulty Univerzity Palackého v Olomouci - Biologie 2, 147-167. Olomouc.

- 1982: Reconstruction of body height based on humerus and femur lengths (material from Czech lands). In: 2nd Anthropological Congress of Aleš Hrdlička, 475-479. Praha.

DROZDOVÁ, E., 1998: Antropologický rozbor kosterních pozůstatků ze stř̌edověkého hřbitova na Dominikánském nám. v Brně. In: Ve službách archeologie 1, 71-74. Brno.

DUFFEK, P. a kol., 2017: Duffek, P.-Těsnohlídek, J.-Těsnohlídková, K.-Prachařová, M.-Skořepová, M., Stavební úpravy Palackého náměstí Počátky, nálezová zpráva, rkp. ulož. v Archaia Brno, o.p.s., č. A020/2014.

FEREMBACH, D.-SCHWIDETZKY, I.-STLOUKAL, M., 1979: Empfehlungen für die Alters- und Geschlechtsdiagnose am Skelett, Homo 30, 1-32.

FLORKOWSKI, A.-KOZLOWSKI, T., 1996: Ocena Wieku szkieletowego dzieci na podstawie wielkości kości, Przegląd Antropologiczny 57 (1-2), 71-86.

HEJHAL, P.-HRUBÝ, P., 2005: Dřevěná architektura 13. století v Jihlavě, Pelhřimově a Humpolci. In: Forum Urbes Medii Aevi II. (Merta, D.-Peška, M., edd.), 126-147. Brno.

HOLUB, P. a kol., 2005: Holub, P.-Kolařík, V.-Merta, D.-Peška, M.-Zapletalová, D.-Zůbek, A., Ke stavu poznání nezděné měšt’anské architektury vrcholně středověkého Brna. In: Forum Urbes Medii Aevi II. (Merta, D.-Peška, M., edd.), 44-101. Brno.

HOLUB, P.-KRČILOVÁ, I.-MARTÍNEK, Z., 2009: Archiv města Počátky 1504-1945 (1967), inventář, rkp. ulož. v MZA - SOkA Pelhřimov, ev. č. 1008.

HRUBÝ, P. a kol., 2006: Hrubý, P.-Jaroš, Z.-Kočár, P.-Malý, K.-Mihályiová, J.-Militký, J.-Zimola, D., Středověká hornická aglomerace na Starých Horách u Jihlavy, PA XCVII, 171-264. 
HRUBÝ, P. a kol., 2009: Hrubý, P.-Hejhal, P.-Kašák, K.-Malý, K.-Valkony, J., Zaniklá barokní sklářská hut' na katastru Nové Vsi u Božejova (okres Pelhřimov). In: Studies in Post-Medieval Archaeology 3 (Žegklitz, J., ed.), 479-500. Praha.

KOČÁR, P.-KOČÁROVÁ, R., 2016: Počátky, zpráva o archeobotanické analýze, výzkumná zpráva z 19. 2. 2016, rkp. ulož. v Archaia Brno, o. p. s., č. A020/2014.

KUČA, K., 2002: Města a městečka v Čechách, na Moravě a ve Slezsku V. Praha.

KUŽELKA, V., 1999: Osteometrie. In: Antropologie. Příručka pro studium kostry (Stloukal, M., ed.), 40111. Praha.

KYNCL, T., 2016: Dendrochronologická analýza vzorků z objektu 0518 v Počátkách, výzkumná zpráva z 23. 6. 2016, rkp. ulož. v Archaia Brno, o.p.s., č. A020/2014.

LOVEJOY, O. C., 1985: Dental wear in the Libben Populatoin: Its Functional Pattern and Role in the Determination of Adult Skeletal Age at Death, American Journal of Physical Anthropology 68, 47-56. DOI: https://doi.org/10.1002/ajpa.1330680105

MALÝ, K., 2016: Mineralogický a chemický rozbor strusek z Počátek (okr. Pelhřimov), výzkumná zpráva z 31. 8. 2016, rkp. ulož. v Archaia Brno, o.p. s., č. A020/2014.

MIČAN, D.-MUSIL, F., 1996: Počátky, věž kostela Narození sv. Jana Křtitele, sondážní průzkum pláště, výzkumná zpráva z června 1996, rkp. ulož. v BRISAMM s.r.o., Jírovcova 38, České Budějovice, č. 308/2801/1.

MURAIL, P. a kol., 2005: Murail, P.-Brůžek, J.-Houéz, F.-Cunha, E., DSP: A Tool for Probabilistic Sex Diagnosis Using Worldwide Variability in Hip-Bone Measurements, Bulletins et Mémoires de la Société d'Anthropologie de Paris 17, 167-176.

NEMESKÉRI, J.-HARSÁNYI, L.-ACSÁDI, G., 1960: Methoden zur Diagnose des Lebensalters von Skelettfunden, Anthropologischer Anzeiger 24, 70-95.

NOVOTNÝ, V., 1985: Determination of Sex from the Talus and Calcaneus, Scripta Medica 58, 437.

Ottův slovník naučný, heslo z Hardeka (autor August Sedláček).

PROCHÁZKA, R., 2007: Deskripční systém brněnské keramiky. Př́iloha 1, PV 48, 234-270.

PROCHÁZKA, R.-PEŠKA, M., 2007: Základní rysy vývoje brněnské keramiky ve 12.-13./14. století, PV 48, 143-232.

SCHAEFER, M.-BLACK, S.-SCHEUER, L., 2009: Juvenile Osteology: A Laboratory and Field Manual. Burlington - San Diego - London.

SCHOTSMAN, E. M. J. a kol., 2015: Schotsman, E. M. J.-Van De Vijver, K.-Wilson, A. S.-Castex, D., Interpreting lime burials. A discussion in light of lime burials at St. Rombout's cemetery in Mechelen, Belgium (10th-18th centuries), Journal of Archaeological Science: Reports 3, 464-479. DOI: https://doi. org/10.1016/j.jasrep.2015.07.006

SLAVÍČKOVÁ, L., 1993: Děkanský úřad Počátky 1636-1949, inventář, rkp. ulož. v MZA - SOkA Pelhřimov, ev. č. 125 .

SJØVOLD, T., 1990: Estimation of stature from long bones utilizing the line of organic correlation, Human Evolution 5, 431-447. DOI: https://doi.org/10.1007/BF02435593

STLOUKAL, M.-HANÁKOVÁ, H., 1978: Die Länge der Längsknochen altslawischer Bevölkerungen unter besonderer Berücksichtung von Wachstumsfragen, Homo 29, 53-69.

UBELAKER, D. H., 1978: Human Skeletal Remains. Excavation, analysis, interpretation. Chicago.

ŠIMÁK, J. V., 1928: Zpovědní seznamy arcidiecéze pražské z r. 1671-1752 V. Bechyňsko. Praha.

VLČEK, E., 1994: Metodika určování zubního věku podle stupně mineralizace chrupu v historické antropologii a paleoantropologii, Stomatologické zprávy 35 (3), 30-39.

WALRATH, D. E.-TURNER, P.-BRU゚ŽEK, J., 2004: Reliability Test of the Visual Assessment of Cranial Traits for Sex Determination, American Journal of Physical Anthropology 125, 132-137. DOI: https://doi. org/10.1002/ajpa.10373

ZAPLETAL, T., 1941: Sborník starožitného města Počátek II, přehled událostí - historické doklady. Jindřichův Hradec.

ŽIVNÝ, M., 2010: Antropologické zpracování lidských kosterních pozůstatků ze hřbitova u kostela sv. Jakuba v Brně. Výsledky paleodemografické a osteometrické analýzy. Brno.

\section{Internetové zdroje}

Josephinische Landesaufnahme: Josephinische Landesaufnahme, M 1 : 28800, Blatt Nr. 199 Böhmen, Staatsarchiv Wien, www.oldmaps.geolab.cz, cit. 20. 1. 2017. 


\section{Zusammenfassung}

\section{Die Ergebnisse der archäologischen Grabung am Palacký-Platz in Počátky (Bezirk Pelhřimov)}

Im Jahr 2015 wurde von der Iglauer Arbeitsstätte der Gesellschaft Archaia Brno während der Sanierung des Palacký-Platzes in Počátky eine großflächige Rettungsgrabung durchgeführt. Die Umgebung von Počátky zählt zu den nur sehr wenig bekannten Regionen, und eine Freilegung im gegebenen Umfang stellte eine außergewöhnliche Gelegenheit dar, einen Einblick in die historische Entwicklung der Stadt zu bekommen. Freigelegt wurden die mit der in der zweiten Hälfte des 13. Jahrhunderts erfolgten Gründung der Stadt und mit ihrem Betrieb im Hoch- und Spätmittelalter zusammenhängenden Situationen, die meisten archäologischen Situationen betrafen jedoch den Zeitraum 16.-19. Jahrhundert. Die jüngsten untersuchten Situationen stammten vom Beginn des 19. Jahrhunderts, als die älteren Situationen durch eine Steinpflasterung auf dem Marktplatz verschlossen wurden.

In der Stadt Počátky stellt Objekt 0518 die älteste erfasste archäologische Situation dar, das im nördlichen Teil des Marktplatzes vor dem Haus mit der Konskriptionsnummer 6 freigelegt wurde. Objekt 0518 stellt das Souterrain eines offenbar oberirdischen Holz-Lehm-Gebäudes dar und kann in die zweite Hälfte des 13. Jahrhunderts datiert werden, sein Untergang dann an die Wende des 13. und 14. Jahrhunderts. Objekt 0518 lieferte wesentliche Informationen über das Aussehen einer nicht gemauerten Architektur, über die Keramikproduktion und über die Nutzung der Landschaft in der Umgebung der Stadt Počátky zur Wende des 13. und 14. Jahrhunderts.

Im Objekt wurde eine archäobotanische Analyse der Fußboden- und Untergangsschichten durchgeführt. Der Komplex an Pflanzenmakroresten aus den Fußbodenschichten des Souterrains 0518 enthielt vor allem Halmfrüchte und deren Unkräuter, ferner befanden sich dort Diasporen von Nutzpflanzen, besonders von Pflückobst und der lokalen Müllplatzvegetation. Die Probe aus der Untergangsverfüllung des Objektes enthielt einen Komplex an verkohltem Flachs mit einer Beimischung von weiteren Feldfrüchten. Die anthrakologische Analyse indizierte eine fortgeschrittene Entwaldung der Umgebung der Stadt Počátky im Hochmittelalter.

Die überwiegend keramische Füllung des Objektes kann ebenfalls in die zweite Hälfte des 13. bis zum Beginn des 14. Jahrhunderts datiert werden. Formenmäßig dominieren hier Töpfe, es tauchen auch Deckel-, Krug-, Öllämpchen- und Schüsselfragmente auf. Von den Topfrändern überwiegen nach oben gezogene, dachförmige und flach nach oben gezogene Ränder, zahlreicher vertreten sind sich verjüngende nach oben gezogene und flache Krausränder, lediglich bei einigen Exemplaren sind gewulstete, umgeschlagene, waagerecht ausgelegte und einfach geknickte Ränder vertreten. Die Verzierungen der Gefäße bestehen aus Rillen, Riefen oder Wellenlinien, ggf. kombiniert, ferner aus vereinzelten Einritzungen. An den Gefäßböden oder den Deckelgriffen befinden sich Marken. Die meisten Fragmente, bei denen die Herstellungsart bestimmt werden konnten, trugen Spuren vom Drehen auf der Töpferscheibe. Im ganzen Objekt kamen Fragmente von Vorratsgefäßen vor. Ein Teil der Verfüllung bildete gebrannte Keramik.

Auf der Nordfläche des Platzes wurden neben dem Souterrain 0518 in geringerer Menge spätmittelalterliche Ablagerungen und Packlagen dokumentiert. In der Fläche des Platzes konnten zahlreiche Nivellierschichten freigelegt werden, die bei den Umbauten abgebrannter Bürgerhäuser nach mehreren großen Bränden der Stadt im Laufe der Neuzeit angelegt wurden. Die jüngste archäologische Situation bringen wir mit den zu Beginn des 19. Jahrhunderts erfolgten rasanten Umgestaltungen des Platzes in Verbindung, als es zur Einebnung des Friedhofsbereichs kam und die oben erwähnten Strukturen durch ein Steinpflaster verschlossen wurden.

Die archäologische Grabung brachte neue Erkenntnisse zur Geschichte und baulichen Entwicklung der St. Johannes-der-Täufer-Kirche. Es wurden mehrere untergegangene Anbauten der Kirche und gotische Stützen des älteren mittelalterlichen Chorraums dokumentiert, der nach dem Brand im Jahr 1662 markant umgebaut wurde. Im Bereich des Chorraums wurden Gräber freigelegt, die sich stratigraphisch eindeutig unter den gotischen Stützen befanden oder durch den Bau des Chorraums beschädigt wurden. Man kann demnach in Betracht ziehen, dass der Kirche in 
ihrer gegenwärtigen Größe in den Anfangszeiten der Stadt ein kleinerer Sakralbau vorausging, der von einem später durch den Bau beschädigten Friedhofsbereich umgeben war.

Im Raum um die Kirche wurde das Areal des zu Beginn des 19. Jahrhunderts verschwundenen städtischen Friedhofs untersucht. Anhand der Orientierung der Gräber und ihren Ausstattungen vermuten wir, dass es ab dem Hochmittelalter bis zum Verschwinden des Friedhofs mehrere Etappen von Beisetzungen der Verstorbenen gab. Der Friedhofsbereich wurde in der Zeit des Mittelalters und der Neuzeit durch eine Steinmauer abgegrenzt, nichtsdestotrotz befanden sich auch außerhalb von ihm Gräber. Man kann davon ausgehen, dass es sich bei ihnen um ältere Bestattungen handeln könnte, die vor dem Bau der Friedhofsmauer erfolgten. Die Ergebnisse der anthropologischen Analyse der gehobenen Individuen entspricht dem Erhaltungszustand der Skelette. Aus dem oben aufgeführten ergibt sich, dass lediglich $26 \%$ das Erwachsenenalter nicht erreichten, jedoch wird diese Zahl wahrscheinlich dadurch verzerrt, dass sich keine Skelette von Kleinkindern erhalten haben. Ansonsten weicht dieser Friedhof bei einem Geschlecherverhältnis von $1: 1,17$ $(\mathrm{M}: \mathrm{W})$ weder hinsichtlich seiner Zusammensetzung der Population, einer durchschnittlichen Größe der Personen von $165 \mathrm{~cm}$, noch durch Varietäten oder pathologische Prozesse von ähnlichen, vergleichbar datierten Friedhöfen auf dem Gebiet Mährens ab. Anhand der untersuchten pathologischen Prozesse wurde eine häufige Anwesenheit von Stress in der Kindheit festgestellt. Mit diesem Stress ist beispielsweise ein Mangel an wichtigen Nährstoffen in der Ernährung oder ernste Viren- oder bakterielle Erkrankungen gemeint. Die Skelette wiesen zumeist beträchtliche Anzeichen für Verschleiß auf, und zwar auch bei relativ jungen Individuen, was von einer größen physischen Anstrengung während des Lebens zeugt. Bei Unfällen oder Krankheiten erfolgten die Behandlungsarten auf keinem sehr hohem Niveau, Das lässt sich beispielsweise an schief zusammengewachsenen Brüchen, häufigen Entzündungen und an Zähnen beobachten, von denen durch Karies lediglich Wurzelstümpfe geblieben waren.

Die hier vorgelegte Studie liefert wesentliche Informationen über die Geschichte der Stadt Počátky. Der interdisziplinäre Ansatz machte es möglich, die Ergebnisse der archäologischen Rettungsgrabung um eine Analyse der Archivquellen, um palynologische und anthrakologische Analysen für die ältesten Fundsituationen und vor allem um eine anthropologische Analyse der von der auf dem ehemaligen städtischen Friedhof erfolgten Grabung stammenden Skelettüberreste zu ergänzen.

Der Hauptteil des vorliegenden Beitrags entstand durch die vom Ministerium für Schulwesen, Jugend und Leibeserziehung gewährte Förderung der speziellen Hochschuluntersuchung Nr. MUNI/A/1279/2016. Für wertvolle Ratschläge möchten wir an dieser Stelle vor allem Doz. Mag. Sandra Sázelová, Ph.D., ferner dann RNDr. Robin Pěniček, Ph.D., und Mag. Martin Čuta, Ph.D., unseren Dank aussprechen. Für die geleistete Hilfe bei der Bearbeitung eines Teils der Kollektion gebührt Mag. Radka Šmídová und Mag. Lenka Jurkovičová unser Dank.

Petr Duffek, Archaia Brno, o. p. s., Židovská 26, 58601 Jihlava, Česká republika, archaiajihlava@volny.cz

Bc. Tomáš Janoušek, Konečného náměstí 2, 60200 Brno, Česká republika, 326922@mail.muni.cz

Bc. Marie Prachařová, Konečného náměstí 2, 60200 Brno, Česká republika, 405762@mail.muni.cz

PhDr. Markéta Skořepová, Ph.D., Masarykovo náměstí 12, 39301 Pelhřimov, Česká republika, m.skorepova@muzeumpe.cz

Bc. Michaela Stančíková, Konečného náměstí 2, 60200 Brno, Česká republika, 394245@mail.muni.cz

Mgr. Jakub Těsnohlídek, Archaia Brno, o. p. s., Židovská 26, 58601 Jihlava, Česká republika, archaiajihlava@volny.cz

Mgr. Kateřina Těsnohlídková, Ústav archeologie a muzeologie Filozofické fakulty Masarykovy univerzity, Arna Nováka 1,602 00 Brno, Česká republika, tesnohlidkova@mail.muni.cz 
